\title{
Genetically Modified and Non-Genetically Modified Food Supply Chains: Co-Existence and Traceability
}


This book is dedicated to:

Sylvie who illuminates my life and supports me every day,

my parents and grandparents without whom nothing would have been.

Yves Bertheau 


\title{
Genetically Modified and Non-Genetically Modified Food Supply Chains: Co-Existence and Traceability
}

\author{
Edited by Yves Bertheau \\ Research Director \\ Institut National de la Recherche Agronomique (INRA) \\ France
}

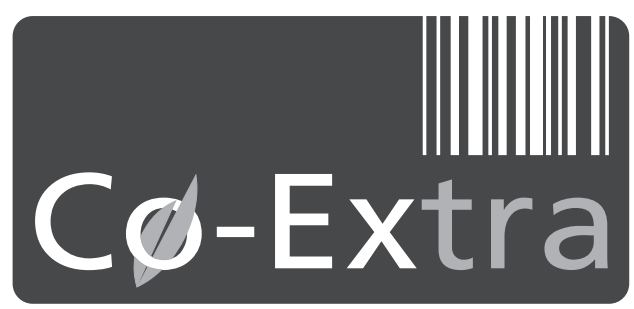

CO-EXISTENCE \& TRACEABILITY

WILEY-BLACKWELL

A John Wiley \& Sons, Ltd., Publication 
This edition first published 2013 @ 2013 by Blackwell Publishing Ltd.

Blackwell Publishing was acquired by John Wiley \& Sons in February 2007. Blackwell's publishing program has been merged with Wiley's global Scientific, Technical and Medical business to form Wiley-Blackwell.

Registered office: $\quad$ John Wiley \& Sons, Ltd, The Atrium, Southern Gate, Chichester, West Sussex, PO19 8SQ, UK

Editorial offices: 9600 Garsington Road, Oxford, OX4 2DQ, UK

The Atrium, Southern Gate, Chichester, West Sussex, PO19 8SQ, UK

2121 State Avenue, Ames, Iowa 50014-8300, USA

For details of our global editorial offices, for customer services and for information about how to apply for permission to reuse the copyright material in this book please see our website at www.wiley.com/wiley-blackwell.

The right of the authors to be identified as the authors of this work has been asserted in accordance with the UK Copyright, Designs and Patents Act 1988.

All rights reserved. No part of this publication may be reproduced, stored in a retrieval system, or transmitted, in any form or by any means, electronic, mechanical, photocopying, recording or otherwise, except as permitted by the UK Copyright, Designs and Patents Act 1988, without the prior permission of the publisher.

Designations used by companies to distinguish their products are often claimed as trademarks. All brand names and product names used in this book are trade names, service marks, trademarks or registered trademarks of their respective owners. The publisher is not associated with any product or vendor mentioned in this book. This publication is designed to provide accurate and authoritative information in regard to the subject matter covered. It is sold on the understanding that the publisher is not engaged in rendering professional services. If professional advice or other expert assistance is required, the services of a competent professional should be sought.

\section{Library of Congress Cataloging-in-Publication Data}

Genetically modified and non-genetically modified food supply chains : co-existence and traceability / edited by Yves Bertheau, Research Director, French National Institute for Agricultural Research (INRA), France. pages $\mathrm{cm}$

Includes bibliographical references and index.

ISBN 978-1-4443-3778-5

1. Genetically modified foods. 2. Food supply. I. Bertheau, Yves, editor of compilation. TP248.65.F66G4573 2012 $664-\mathrm{dc} 23$

A catalogue record for this book is available from the British Library.

Wiley also publishes its books in a variety of electronic formats. Some content that appears in print may not be available in electronic books.

Cover images (clockwise): († iStockphoto.com/YangYin; () iStockphoto.com/webphotographeer; () iStockphoto.com/ AVTG; () iStockphoto.com/sansubba; @ iStockphoto.com/Tupungato; (๑) iStockphoto.com/R-J-Seymour;

(C) iStockphoto.com/4774344sean; (c) iStockphoto.com/TommL

Cover design by www.hisandhersdesign.co.uk

Set in 9.5/12 pt Times by Toppan Best-set Premedia Limited 


\section{Contents}

List of Contributors

xiii

Foreword

G. Riba. Vice-Chairman of INRA

1 Introduction to the GM and Non-GM Supply Chain Co-Existence and Traceability 3 Y. Bertheau, J. Davison

$\begin{array}{llr}1.1 & \text { Introduction } & 3 \\ 1.2 & \text { GMO Development } & 3 \\ 1.3 & \text { Opinions and Attitudes of European Citizens and Consumers } & 4 \\ 1.4 & \text { The Different Regulatory Frames and Risk Perception } & 6 \\ 1.5 & \text { European Traceability and Co-Existence Frames } & 8 \\ 1.6 & \text { Other Issues } & 11 \\ 1.7 \quad \text { Conclusion } & 12 \\ \text { References } & 12\end{array}$

$\begin{array}{ll}\text { Part 2: } & \text { Managing Gene Flow }\end{array}$

Contributions of Pollen and Seed to Impurity in Crops - A Comparison of Maize,
Oilseed Rape and Beet

$\begin{array}{ll}\text { G.R. Squire, J. Lecomte, A. Hüsken, J. Soukup, A. Messéan } & 23 \\ 2.1 \quad \text { Introduction } & \end{array}$

$\begin{array}{lll}2.2 & \text { Maize } & 23\end{array}$

$\begin{array}{ll}2.3 & \text { Oilseed Rape } \\ 2.4 & 26\end{array}$

$\begin{array}{lll}2.4 & \text { Beet } & 29\end{array}$

2.5 Comparison of Species Based on Plant Traits 30

$\begin{array}{ll}\text { References } & 32\end{array}$

3 Co-Existence Issues of GM Sugar Beet $\quad 35$

H. Darmency

$\begin{array}{lll}3.1 & \text { Introduction } & 35\end{array}$

$\begin{array}{lll}3.2 & \text { Sugar Beet in the World } & 35\end{array}$

3.3 Overview of Sugar Beet Biology and Agronomy 36

$\begin{array}{lll}3.4 & \text { Pre-cultivation Co-existence Issues } & 39\end{array}$

3.5 Consequences of Co-existence for the Cropping System in a Region 42

3.6 Consequences of Co-existence for the Genetic Resources 45

3.7 Post-harvest Co-existence Issues $\quad 45$

$\begin{array}{ll}3.8 & \text { Conclusion }\end{array}$

References 
4 Ex Ante Evaluation of Gene Flow in Oilseed Rape with Cropping System Models

N. Colbach

4.1 Introduction

4.2 Modelling Approach

4.3 The Simulation Methodology

4.4 Perspectives

References

5 Biological Containment Strategies for Transgenic Crops

R.A. de Maagd, K. Boutilier

5.1 Introduction

5.2 Auxotrophy

5.3 Inhibition of Flowering and Complete Sterility

5.4 Cleistogamy

5.5 Transgene Excision

5.6 Chloroplast Transformation

5.7 Male Sterility

5.8 Parthenocarpy

5.9 Apomixis

5.10 Reduced Shattering

5.11 Blocking Seed Germination

5.12 Inhibiting Seed Dormancy

5.13 Transgenic Mitigation

5.14 Concluding Remarks

References

6 Long-Distance Pollen Flow in Large Fragmented Landscapes

Y. Brunet, S. Dupont, S. Delage, D. Garrigou, D. Guyon, S. Dayau, P. Tulet,

J.-P. Pinty, C. Lac, J. Escobar, A. Audran, X. Foueillassar

6.1 Introduction 79

$\begin{array}{lr}\text { 6.2 Evidence for Long-distance Cross-pollination of Maize } & 80\end{array}$

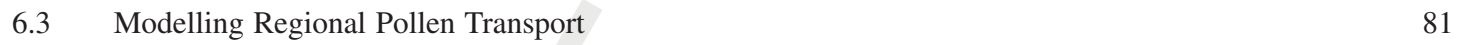

6.4 Model Evaluation $\quad 83$

6.5 Simulated Regional Pollen Dispersal $\quad 84$

\begin{tabular}{ll}
6.6 & Conclusions and Perspectives \\
\hline
\end{tabular}

References

7 Current and Future Availability of Non-Genetically Modified Soybean Seeds in the USA,

Brazil and Argentina

J. Milanesi

7.1 Introduction

7.2 Global Overview of the Soybean and Soybean Seed Markets and Related Short-term Issues

7.3 Soybean Plant Breeding and Availability of Non-GM Soybean Seeds

$\begin{array}{lll}7.4 & \text { The Future of Non-GM Plant Breeding } & 104\end{array}$

$\begin{array}{llr}7.5 & \text { Conclusion } & 109\end{array}$

$\begin{array}{lr}\text { References } & 110\end{array}$

Part 3: Co-Existence in Food and Feed Supply Chains 113

8 Consumers' Opinions and Attitudes Towards Co-existence of GM and Non-GM Food Products 
$\begin{array}{ll}\text { 8.5 Conclusions } & 124\end{array}$

References

9 Evaluation of Collection Strategies for Landscape and Product Flow Management 127

F.C. Coléno, F. Angevin

$\begin{array}{ll}9.1 & \text { Introduction } \\ 9.2 & 127\end{array}$

9.2 Evaluation of Co-Existence Management Strategies for Grain Merchants 128

$\begin{array}{ll}\text { 9.3 Evaluation of Collection Strategies at the Landscape Level } & 134\end{array}$

$\begin{array}{lll}9.4 & \text { Conclusion } & 135\end{array}$

References 138

10 Empirical Analysis of Co-Existence in Commodity Supply Chains 141

N. Gryson, M. Eeckhout, A. Messéan, L-G. Soler, B. Lécroart, A. Trouillier, M. Le Bail,

J. Bez, R. Bourgier, J. Copeland, M. Gylling, M. Maciejczak, V. Meglič, K. Menrad,

A. Gabriel, M. Stolze, C. Tapia, G. Ghezan, V. Pelaez, R. Rocha dos Santos

$\begin{array}{lll}10.1 & \text { Introduction } & 141\end{array}$

10.2 Framework 141

$\begin{array}{llr}10.3 & \text { Methodology } & 143\end{array}$

$\begin{array}{llr}10.4 & \text { Results } & 145\end{array}$

10.5 Conclusion $\quad 155$

$\begin{array}{ll}\text { References } & 157\end{array}$

11 Modelling and Assessing the Impacts of the Co-Existence Between GM and

non-GM Supply Chains: The Starch Maize Supply Chain Example 161

B. Lecroart, A. Messéan, L-G. Soler

11.1 Introduction $\quad 161$

11.2 Material Flow and Risks of Commingling in the Starch Maize Supply Chain 162

11.3 Model Description 163

$\begin{array}{lll}11.4 & \text { Sensitivity Analysis } & 167\end{array}$

$\begin{array}{ll}11.5 & \text { Results and Discussion } \\ 11.6 & \text { Conclus }\end{array}$

$\begin{array}{lll}11.6 & \text { Conclusion } & 173\end{array}$

$\begin{array}{ll}\text { References } & 173\end{array}$

12 Costs of Segregation and Traceability Between GM and Non-GM Supply Chains of Single Crop and Compound Food/Feed Products

K. Menrad, A. Gabriel, J. Bez, M. Gylling, A. Larsen, M. Maciejczak, M. Stolze, N. Gryson,

M. Eeckhout, N. Pensel, R. Rocha dos Santos, A. Messéan

$12.1 \quad$ Objectives

$\begin{array}{ll}\text { 12.2 Introduction and Regulatory Framework } & 177\end{array}$

$\begin{array}{ll}12.3 & 179\end{array}$

$\begin{array}{lll}12.4 & \text { Results } & 181\end{array}$

$\begin{array}{llr}12.5 & \text { Conclusions } & 189\end{array}$

$\begin{array}{ll}\text { References } & 191\end{array}$

13 Labelling and Co-Existence Regulation of GMOs and Non-GMOs: An Economic Perspective 193

M. Desquilbet, S. Poret

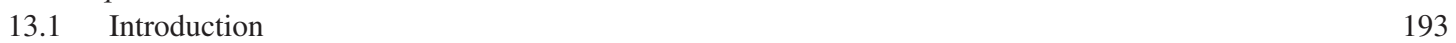

13.2 To What Extent Do Consumers Value Non-GM Goods Over GM Goods and Why? 194

13.3 Labelling May Improve Welfare But Is Not A First-Rank Policy to Address Consumer Concerns 201

13.4 Externality Costs of Co-Existence Without A Co-existence Regulation 204 
13.5 Co-Existence Regulation 205

$\begin{array}{llr}13.6 & \text { Conclusion } & 209\end{array}$

$\begin{array}{ll}\text { Appendix } & 210\end{array}$

$\begin{array}{ll}\text { References } & 211\end{array}$

14 Co-Existence and Traceability in Supply Chains: A Case Study on Belgian Compound Feed 215

N. Gryson, M. Eeckhout

\begin{tabular}{ll}
14.1 & Compound Feed Production \\
\hline
\end{tabular}

$\begin{array}{ll}14.2 & \text { Traceability and Segregation Systems } \\ 14.3 & 218\end{array}$

$\begin{array}{lll}14.3 & \text { Other Costs and Benefits along the Supply Chain } & 224\end{array}$

14.4 Changing Strategies 230

\begin{tabular}{ll}
14.5 & Conclusion \\
\hline
\end{tabular}

$\begin{array}{ll}\text { References } & 237\end{array}$

Part 4: Traceability and Controls in Food and Feed Supply Chains 243

15 GMO Sampling Strategies in Food and Feed Chains 245

R. Onori, J. Šuštar-Vozlič, G. Bellocchi, G. Berben, A. Blejec, C. Brera, Z. Čergan (Deceased),

M. Debeljak, M. De Giacomo, M. De Vivo, T. Esteve, E. Janssen, P. Kozjak, F. Leprince,

R. Macarthur, A. Malcevchi, N. Marmiroli, V. Meglič, E. Melé, J. Messeguer, M. Miraglia,

A. Nadal, R. Oger, E. Palmaccio, M. Pla, V. Planchon, E. Prantera, K. Rostohar, B. Vrščaj

$15.1 \quad$ Introduction

15.2 The EC Recommendation 2004/787: Methodologies, Applications and Limitations 246

15.3 Co-Extra Results for Different Scenarios of the Food and Feed Chain 246

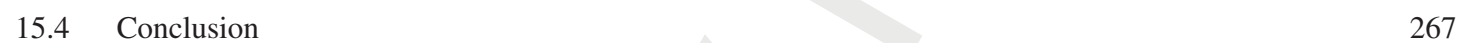

$\begin{array}{ll}\text { References } & 269\end{array}$

16 Harmonised Reference Genes and PCR Assays for GMO Quantification 273

I. Taverniers, N. Papazova, T. Allnutt, S. Baumler, Y. Bertheau, T. Esteve, R. Freyer,

K. Gruden, B. Kuznetzov, J. Luis La Paz, A. Nadal, M. Pla, J. Vojvoda, D. Wulff, D. Zhang

16.1 Introduction: Regulatory Framework on Reference Assays 273

$\begin{array}{lll}16.2 & \text { Overview of Existing Reference Assays } & 274\end{array}$

16.3 Reliability Testing of Existing Reference Assays 274

16.4 Harmonised Definitions, Terminology and Technical Criteria for Designing

New Reference Assays $\quad 277$

16.5 Core Collections for Specificity, Uniformity and Stability Testing of Reference Assays for
GMO Quantification

\begin{tabular}{ll}
16.6 & Conclusion \\
\hline
\end{tabular}

$\begin{array}{ll}\text { References } & 290\end{array}$

17 The Modular Approach in GMO Quality Control and Enforcement Support Systems 293

M. Van den Bulcke, G. Bellocchi, G. Berben, M. Burns, K. Cankar, M. De Giacomo,

K. Gruden, A. Holst-Jensen, A. Malcewsky, M. Mazzara, R. Onori, N. Papazova,

E. Parlouer, I. Taverniers, S. Trapmann, D. Wulff, D. Zhang

17.1 Enforcing the Legal GMO Framework by Harmonised Control Analysis 293

17.2 Validation of GMO Test Methods: A Modular Versus a Global Approach 294

17.3 Co-Extra Assessment of the Modular Approach in GMO Analysis 295

17.4 Decision Support Systems (DSS) Within a Modular Approach 303

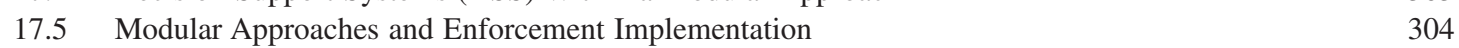

$\begin{array}{lll}17.6 & \text { Conclusion } & 304\end{array}$

References 
18 Reliability and Cost of GMO Detection

K. Gruden, T.R. Allnutt, M. Ayadi, S. Baeumler, C. Bahrdt, G. Berben, K.G. Berdal, Y. Bertheau,

C. Bøydler Andersen, P. Brodmann, M. Buh Gašparič, M.J. Burns, A.M. Burrel, K. Cankar,

T. Esteve, A. Holst-Jensen, A.B. Kristoffersen, J. La Paz, D. Lee, A. Lovseth, R. Macarthur,

D. Morisset, M. Pla, R.B. Rud, C. Skjaret, T. Tengs, H. Valdivia, D. Wulff, D. Zhang, J. Žel

18.1 Introduction

18.2 Accurate Determination of the Limit of Detection Associated with GMO Analysis

18.3 Improvements in the Limit of Quantification

18.4 Reliability of GMO Quantification

18.5 DNA Extraction from Highly Processed Matrixes

18.6 Evaluation of Alternative Chemistries in Real-time PCR

18.7 Evaluation of Different Machines for GMO Quantification by Real-time PCR 321

$\begin{array}{lll}18.8 & \text { Evaluation of Automation Potential in GMO Detection } & 324\end{array}$

\begin{tabular}{ll}
18.9 & Conclusions and Perspectives \\
\hline
\end{tabular}

$\begin{array}{ll}\text { References } & 329\end{array}$

19 New Multiplexing Tools for Reliable GMO Detection

M. Pla, A. Nadal, V. Baeten, C. Bahrdt, G. Berben, Y. Bertheau, A. Coll, J.P. van Dijk,

D. Dobnik., J.A. Fernandez Pierna, K. Gruden, S. Hamels, A. Holck, A. Holst-Jensen,

E. Janssen, E.J. Kok, J.L. La Paz, V. Laval, S. Leimanis, A. Malcevschi, N. Marmiroli,

D. Morisset, T.W. Prins, J. Remacle, G. Ujhelyi, D. Wulff

19.1 Introduction

19.2 From Duplex to Oligoplex PCR

352

19.4 High Grade Multiplex Approaches $\quad 356$

$\begin{array}{ll}19.5 & \text { Conclusions } \\ \end{array}$

$\begin{array}{ll}\text { References } & 361\end{array}$

20 Towards Detection of Unknown GMOs

A. Holst-Jensen, K.G. Berdal, Y. Bertheau, M. Bohanec, J. Bohlin, M. Chaouachi,

K. Gruden, S. Hamels, E.J. Kok, A. Krech, A.B. Kristoffersen, V. Laval, S. Leimanis,

M. Løvoll, D. Morisset, A. Nemeth, N. Papazova, T.W. Prins, J. Remacle, P. Richl,

T. Ruttink, I. Taverniers, T. Tengs, J.P. van Dijk, D. Wulff, J. Žel, H. Zhang, M. Žnidaršič

20.1 Introduction

20.2 Classifications of GMOs Relevant to Detection

10.3 Detection of GMOs - A Short Review
20.4 Detection of Unauthorised GMOs

\begin{tabular}{ll}
20.4 & Detection of Unauthorised GMOs \\
\hline
\end{tabular}

20.5 Detection of Unknown GMOs 379

\begin{tabular}{ll}
20.6 & Conclusion \\
\hline
\end{tabular}

$\begin{array}{ll}\text { References } & 380\end{array}$

21 Method Validation and Reference Materials 383

G. Bellocchi, Y. Bertheau, M. De Giacomo, A. Holst-Jensen, R. Macarthur,

M. Mazzara, R. Onori, I. Taverniers, M. van den Bulcke, S. Trapmann

21.1 The Concept of Validation

21.2 Single Laboratory Validation

21.3 Collaborative Validation of Methods

21.4 Innovative Statistical Approaches for Method Validation

21.5 The Modular Approach

21.6 The Use of CRMs (Certified Reference Materials) and Possible Alternatives in View of 
21.7 Addressing the Compatibility of the Control Plans throughout the Chains 393

\begin{tabular}{ll}
21.8 & Conclusion and Perspectives \\
\hline
\end{tabular}

References $\quad 398$

Part 5: Legal Regimes, Liability and Redress Issues 403

22 Liability and Redress Options for Damage Caused by GMOs 405

B.A. Koch

22.1 Introduction

22.2 Prevention of Future Harm -406

22.3 Redress for Damage $\quad 406$

$\begin{array}{llr}22.4 & \text { Outlook } & 412\end{array}$

References $\quad 413$

23 Legal Issues, an Overview on Co-Existence Policies: Technological Pluralism, Confidence Economy, Transnational Supply Chains

M.-A. Hermitte, S. Anvar, M. Bonin, N. Bargues, G. Canselier, S. Desmoulin, A. Langlais, J.C. Varela

23.1 Introduction

23.2 The Juridical Nature of Co-Existence Policy 416

23.3 Keypoints of Supply Chain Structuring 419

23.4 Import Supply Chains and GMOs 424

23.5 A Liability System Adapted to a Controversial Technology 428

\begin{tabular}{ll}
23.6 & Conclusion \\
\hline
\end{tabular}

$\begin{array}{lr}\text { References } & 430\end{array}$

24 The Judge's Role Concerning Science in Precautionary Measures: A Shift from Guide

to Arbitrator

C. Noiville

$\begin{array}{lll}24.1 & \text { Introduction } & 433\end{array}$

24.2 The Judge: A Guide to Administrative Action 434

24.3 Judges as Arbitrators of Scientific Assessments?

24.4 Conclusion $\quad 454$

References $\quad 454$

\begin{tabular}{ll} 
Part 6: & Data Integration and DSS \\
\hline
\end{tabular}

25 The Co-Extra Decision Support System: A Model-Based Integration of Project Results 461

M. Bohanec, Y. Bertheau, C. Brera, K. Gruden, A. Holst-Jensen, E.J. Kok, B. Lécroart,

A. Messéan, M. Miraglia, R. Onori, T.W. Prins, L-G. Soler, M. Žnidaršič

25.1 Introduction $\quad 461$

25.2 Approach and Methodology $\quad 462$

25.3 Components of the Co-Extra DSS 464

25.4 Assessment of Analytical Methods $\quad 464$

25.5 Assessment of Sampling Methods 472

25.6 Assessment of Products Using Traceability Data 477

25.7 Assessment of Processes 482

25.8 Database and Web-based Implementation $\quad 485$

\begin{tabular}{ll}
25.9 & Conclusions \\
\hline
\end{tabular}

References 
Part 7: Related Issues $\quad 491$

26 Integration of Co-Extra Results in EU Tools for Traceability 493

G. van den Eede, D. Plan

26.1 Overview of EU Legislation on GMOs 493

26.2 Achievements in the EU Harmonisation of GMO Analysis 497

26.3 Challenges Ahead $\quad 499$

\begin{tabular}{lr}
26.4 & Conclusion \\
\hline
\end{tabular}

References $\quad 518$

27 Labelling and Detection of GM Crops and Derived Products: Regulatory Frameworks and Research Issues in East Asia

D. Zhang, L. Yang, C.-H. Lee, S-H. Lee, B.-J. Kuo, K. Kitta, M. Tachikawa
$27.1 \quad$ Introduction

$\begin{array}{ll}27.2 & \text { People's Republic of China } \\ 27.3 & 522\end{array}$

$\begin{array}{lll}27.3 & \text { Korea } & 527\end{array}$

$\begin{array}{lll}27.4 & \text { Taiwan } & 532\end{array}$

$\begin{array}{ll}27.5 & 534\end{array}$

\begin{tabular}{ll}
27.6 & Conclusion \\
\hline
\end{tabular}

$\begin{array}{ll}\text { References } & 539\end{array}$

28 Maintaining a Supply of Non-GM Feed - A Strategic Issue for European Regional Agriculture 543

$\begin{array}{ll}R . ~ L a y a d i & 543 \\ 28.1 \quad \text { Introduction } & \end{array}$

$\begin{array}{lll}28.1 & \text { Introduction } & 543 \\ 28.2 & \text { The GMO-free Regions Network } & 544\end{array}$

28.3 The Feed Question: A Major Issue for Regional Agriculture $\quad 544$

28.4 GMO-free Agriculture, a Vital Issue for Regions 548

28.5 Getting a Solid Strategic and Tactical Background: Lessons from the Cold War 550

28.6 An Essential Question: Who Decides On the Definition of A Market? 554

References $\quad 555$

29 A Geographical Approach to the European Policy for the Co-Existence of GMO and Non-GMO Crops 563

E. Glon

29.1 Introduction $\quad 563$

29.2 EU Scenarios for the Co-Existence of GM and Non-GM Crops 564

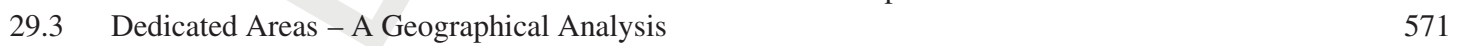

29.4 A Few Lines for Thought with Regard to Co-Existence in Territories 580

\begin{tabular}{ll}
29.5 & Conclusion \\
\hline
\end{tabular}

$\begin{array}{ll}\text { References } & 587\end{array}$

30 Segregating Supply Chains: a Cost-Benefit Perspective $\quad 591$

J.K. Hammitt, W.W. Wilson

$\begin{array}{lll}30.1 & \text { Introduction } & 591\end{array}$

\begin{tabular}{ll}
30.2 & Social Benefits of Co-Existence \\
\hline
\end{tabular}

30.3 Consumer Valuation of GMO-free Foods $\quad 593$

30.4 Background on Developments in North American Wheat 595

30.5 Costs of Segregating Wheat to Conform to EU Traceability Standards 595

30.6 Contract Mechanisms to Facilitate Co-Existence 596

$\begin{array}{llr}30.7 & \text { Summary and Implications } & 602\end{array}$

\begin{tabular}{ll}
30.8 & Conclusion \\
\hline
\end{tabular}

References $\quad 603$ 
31 Co-Existence and Traceability in the EU Versus IP Systems in Third Countries 605

R. Rocha dos Santos, N. Pensel, R. Green

$31.1 \quad$ Introduction $\quad 605$

31.2 Mercosur and Europe: Different But Complementary 606

$\begin{array}{ll}31.3 & \text { The GM Soybeans in Mercosur } \\ 31.4 & 606\end{array}$

31.4 Food Regulation $\quad 609$

$\begin{array}{lll}31.5 & \text { EU, Mercosur and Traceability } & 610\end{array}$

$\begin{array}{ll}31.6 & \text { Contracts and Private Regulations } \\ 31.7 & 611\end{array}$

31.7 Third Party Certification Companies, the Key Players $\quad 612$

31.8 The Traders' Role $\quad 613$

$\begin{array}{ll}31.9 & \text { Final Considerations } \\ \end{array}$

References $\quad 615$

Part 8: Conclusion $\quad 617$

32 GM and Non-GM Supply Chain Co-Existence and Traceability: Context and Perspectives 619

Y. Bertheau

$\begin{array}{lll}32.1 & \text { Introduction } & 619\end{array}$

$\begin{array}{lr}32.2 & 619\end{array}$

$\begin{array}{llr}32.3 & \text { Co-Existence } & 624\end{array}$

$\begin{array}{ll}32.4 & \text { Traceability } \\ 32.5 & \text { Conclusion }\end{array}$

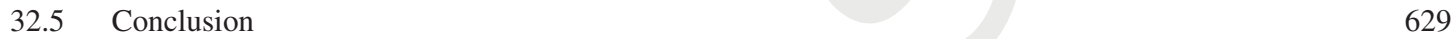

$\begin{array}{lr}\text { References } & 630\end{array}$

Index

643

Plate section fall between pages 314 and 315 


\section{List of Contributors}

\section{T. Allnutt}

The Food and Environment Research Agency, York, UK

\section{F. Angevin}

Institut National de la Recherche Agronomique (INRA), Thiverval-Grignon, France

\section{S. Anvar}

Centre de Recherche en Droit des Sciences et Techniques, Université Paris I, CNRS, Paris, France

\section{A. Audran}

Arvalis - Institut du végétal, Montardon, France

\section{Ayadi}

Institut National de la Recherche Agronomique (INRA), Versailles, France

\section{Baeten}

CRA-W, Centre wallon de Recherches agronomiques, Gembloux, Belgium

\section{Bahrdt}

Eurofins GeneScan GmbH, Freiburg, Germany

\section{N. Bargues}

Centre de Recherche en Droit des Sciences et Techniques, Université Paris I, CNRS, Paris, France

\section{S. Baumler}

Eurofins GeneScan GmbH, Freiburg, Germany

\section{G. Bellocchi}

JRC-IHCP, European Commission Joint Research Centre, Institute for Health and Consumer ProtectionMolecular Biology and Genomics, Ispra, Italy

\section{G. Berben}

CRA-W, Centre wallon de Recherches agronomiques, Gembloux, Belgium

\section{K.G. Berdal}

National Veterinary Institute, Oslo, Norway

\section{Y. Bertheau}

Institut National de la Recherche Agronomique (INRA), Versailles, France

\section{J. Bez}

FhG-IVV, Fraunhofer-Gesellschaft zur Förderung der angewandten Forschung, Institute of Process Engineering and Packaging, Freising, Germany

\section{A. Blejec}

National Institute of Biology, Ljubljana,

Slovenia

\section{Bohanec}

Jožef Stefan Institute, Department of Knowledge Technologies, Ljubljana, Slovenia; University of Nova Gorica, Nova Gorica, Slovenia

\section{J. Bohlin}

National Veterinary Institute, Oslo, Norway

\section{Bonin}

Centre de Recherche en Droit des Sciences et Techniques, Université Paris I, CNRS, Paris, France

\section{R. Bourgier}

Institut National de la Recherche Agronomique (INRA), Thiverval-Grignon, France

\section{K. Boutilier}

Bioscience Business Unit, Plant Research International, Wageningen University and Research Center,

Wageningen, Netherlands

\section{Bøydler Andersen}

National Veterinary Institute, Oslo, Norway 


\section{Brera}

ISS, National Institute of Health, Rome, Italy

\section{P. Brodmann}

Biolytix, Witterswil, Switzerland

\section{Y. Brunet}

Institut National de la Recherche Agronomique (INRA), Villenave d'Ornon, France

\section{Buh Gašparič}

National Institute of Biology (NIB), Department of Biotechnology and Systems Biology, Ljubljana, Slovenia

\section{Burns}

Laboratory of the Government Chemist, Analytical Technology, London, UK

\section{A.M. Burrel}

Laboratory of the Government Chemist, Analytical Technology, London, UK

\section{K. Cankar}

National Institute of Biology (NIB), Department of Biotechnology and Systems Biology, Ljubljana, Slovenia

\section{G. Canselier}

Centre de Recherche en Droit des Sciences et Techniques, Université Paris I, CNRS, Paris, France

\section{Z. Čergan (Deceased)}

Agricultural Institute of Slovenia, Ljubljana, Slovenia

\section{Chaouachi}

Institut National de la Recherche Agronomique (INRA) Versailles, France

\section{N. Colbach}

Institut National de la Recherche Agronomique (INRA), Dijon, France

\section{F.C. Coléno}

Institut National de la Recherche Agronomique (INRA), Thiverval-Grignon, France

\section{A. Coll}

Institute of Agro-Food Technology INTEA, Universitat de Girona, Girona, Spain

${ }^{\dagger}$ (deceased).

\section{J. Copeland}

The Food and Environment Research Agency, York, UK

\section{Costa-Font}

CREDA-UPC-IRTA, Barcelona, Spain

\section{H. Darmency}

Institut National de la Recherche Agronomique (INRA), Dijon, France

\section{J. Davison}

Institut National de la Recherche Agronomique (INRA), Versailles, France (retired)

\section{S. Dayau}

Institut National de la Recherche Agronomique (INRA), Villenave d'Ornon, France

\section{R.A. de Maagd}

Bioscience Business Unit, Plant Research International, Wageningen University and Research Center,

Wageningen, Netherlands

\section{M. de Giacomo}

ISS, National Institute of Health, Rome, Italy

\section{M. de Vivo}

ISS, National Institute of Health, Rome, Italy

\section{Debeljak}

Jožef Stefan Institute, Ljubljana, Slovenia

\section{S. Delage}

Institut National de la Recherche Agronomique (INRA), Villenave d'Ornon, France

\section{S. Desmoulin}

Centre de Recherche en Droit des Sciences et Techniques, Université Paris I, CNRS, Paris, France

\section{Desquilbet}

Toulouse School of Economics and Institut National de la recherche Agronomique (INRA), Toulouse, France

\section{Dobnik}

Dept. of Biotechnology and Systems Biology, National Institute of Biology, Ljubljana, Slovenia

\section{S. Dupont}

Institut National de la Recherche Agronomique (INRA), Villenave d'Ornon, France 


\section{Eeckhout}

Department of Food Science and Technology, Faculty of Applied Bio-Sciences Engineering, University College Ghent, Belgium

\section{J. Escobar}

Laboratoire d'Aérologie, Toulouse, France

\section{T. Esteve}

Centre de Recerca en Agrigenòmica (CRAG), Barcelona, Spain; Consorci CSIC-IRTA and IBMB-CSIC,

Barcelona, Spain

\section{J.A. Fernandez Pierna}

CRA-W, Centre wallon de Recherches agronomiques, Gembloux, Belgium

\section{Foueillassar}

Arvalis - Institut du végétal, Montardon, France

\section{R. Freyer}

Eurofins GeneScan GmbH, Freiburg, Germany

\section{A. Gabriel}

Straubing Center of Science, Weihenstephan-Triesdorf University of Applied Sciences, Germany

\section{Garrigou}

Institut National de la Recherche Agronomique (INRA), Villenave d'Ornon, France

\section{G. Ghezan}

INTA, Instituto Nacional de Tecnología Agropecuaria, Argentina

\section{J.M. Gil}

CREDA-UPC-IRTA, Barcelona, Spain

\section{E. Glon}

Lille University of Science and Technology, Department of Geography and Town and Country Planning, TVES laboratory, Villeneuve d'Ascq, France

\section{R. Green}

Institut National de la recherche Agronomique (INRA), Ivry-sur-Seine, France (retired)

\section{K. Gruden}

Department of Biotechnology and Systems Biology, National Institute of Biology (NIB), Ljubljana, Slovenia

\section{N. Gryson}

Department of Food Science and Technology, Faculty of Applied Bio-Sciences Engineering, University College Ghent, Belgium

\section{Guyon}

Institut National de la Recherche Agronomique (INRA), Villenave d'Ornon, France

\section{Gylling}

FOI, Institute of Food and Resource Economics, University of Copenhagen, Denmark

\section{S. Hamels}

EAT, Eppendorf Array Technologies SA, Namur, Belgium

\section{J.K. Hammitt}

Harvard Center for Risk Analysis, Harvard School of Public Health, Harvard University, Boston, USA

\section{M.-A. Hermitte}

Centre de Recherche en Droit des Sciences et Techniques, Université Paris I, CNRS, Paris, France

\section{A. Holck}

Nofima mat AS, Aas, Norway

\section{A. Holst-Jensen}

National Veterinary Institute, Oslo, Norway

\author{
A. Hüsken \\ Julius Kühn Institute, Federal Research Centre for \\ Cultivated Plants (JKI), Institute for Biosafety of \\ Genetically Modified Plants, Braunschweig, Germany

\section{E. Janssen} \\ CRA-W, Centre wallon de Recherches agronomiques, \\ Gembloux, Belgium
}

\section{K. Kitta}

National Food Research Institute, Ibaraki, Japan

\section{B.A. Koch}

Institut für Zivilrecht, Universität Innsbruck, Innsbruck, Austria

\section{E.J. Kok}

RIKILT Wageningen UR, Wageningen, The

Netherlands 


\section{P. Kozjak}

Agricultural Institute of Slovenia, Ljubljana, Slovenia

\section{A. Krech}

Eurofins GeneScan GmbH, Freiburg, Germany.

\section{A.B. Kristoffersen}

National Veterinary Institute, Oslo, Norway

\section{B.-J. Kuo}

National Chung Hsing University, Taichung, Taiwan

\section{B. Kuznetzov}

Center Bioengineering RAS, Russia

\section{J.L. La Paz}

Centre de Recerca en Agrigenòmica CSIC-IRTA-UAB (CRAG), Barcelona, Spain

\section{Lac}

CNRM, Météo-France, Toulouse, France

\section{A. Langlais}

Centre de Recherche en Droit des Sciences et Techniques, Université Paris I, CNRS, Paris, France

\section{A. Larsen}

FOI, Institute of Food and Ressource Economics, University of Copenhagen, Denmark

\section{Laval}

Institut National de la Recherche Agronomique (INRA), Versailles, France

\section{R. Layadi}

Conseil Régional de Bretagne, Rennes, France

\section{Le Bail}

Institut National de la Recherche Agronomique (INRA), and AgroParisTech, Thiverval-Grignon France

\section{J. Lecomte}

Université Paris-Sud; CNRS, Orsay, and AgroParisTech, Paris, France

\section{B. Lécroart}

Institut National de la Recherche Agronomique (INRA), Thiverval-Grignon, France

\section{C.-H. Lee}

Rural Development Administration, Suwon, Korea

\section{Lee}

National Institute of Agricultural Botany, Cambridge, UK

\section{S.H. Lee}

National Agricultural Products Quality Management Service, Korea

\section{S. Leimanis}

EAT, Eppendorf Array Technologies SA, Namur, Belgium

\section{F. Leprince}

Arvalis - Institut du végétal, Montardon, France

\section{Løvoll}

National Veterinary Institute, Oslo, Norway

A. Løvseth

National Veterinary Institute, Oslo, Norway

\section{J. Luis La Paz}

Consorci CSIC-IRTA and IBMB-CSIC, Barcelona, Spain

\section{R. Macarthur}

The Food and Environment Research Agency, York, UK

\section{Maciejczak}

Warsaw University of Life Sciences - SGGW, Poland

\section{A. Malcevschi}

Department of Environmental Sciences, University of Parma, Parma, Italy

\section{N. Marmiroli}

Department of Environmental Sciences, University of Parma, Parma, Italy.

\section{Mazzara}

JRC-IHCP, European Commission Joint Research Centre, Institute for Health and Consumer Protection, Ispra, Italy

\section{Meglič}

Agricultural Institute of Slovenia, Ljubljana, Slovenia

\section{E. Melé}

Centre de Recerca en Agrigenòmica (CRAG),

Barcelona, Spain 


\section{K. Menrad}

Straubing Center of Science, Weihenstephan-Triersdorf University of Applied Sciences, Germany

\section{A. Messéan}

Institut National de la Recherche Agronomique (INRA), Thiverval-Grignon, France

\section{J. Messeguer}

Centre de Recerca en Agrigenòmica (CRAG),

Barcelona, Spain

\section{Miraglia}

ISS, National Institute of Health, Rome, Italy

\section{J. Milanesi}

Toulouse School of Economics and Institut National de la recherche Agronomique (INRA), Toulouse, France

\section{Morisset}

Department of Biotechnology and Systems Biology, National Institute of Biology, Ljubljana, Slovenia

\section{A. Nadal}

Centre de Recerca en Agrigenòmica (CRAG), Barcelona, Spain; Institute of Agro-Food Technology INTEA, Universitat de Girona, Girona, Spain

\section{A. Nemeth}

Eurofins GeneScan GmbH, Freiburg, Germany

C. Noiville

Centre de Recherche en Droit des Sciences et Techniques, Université Paris I, CNRS, Paris, France

\section{R. Oger}

University of Parma, Italy

\section{R. Onori}

ISS, National Institute of Health, Rome, Italy

\section{E. Palmaccio}

ISS, National Institute of Health, Rome, Italy

\section{N. Papazova}

Scientific Institute of Public Health (IPH), Section Biosafety and Biotechnology, Brussels, Belgium; ILVO, Institute for Agricultural and Fisheries Research, Merelbeke, Belgium

\section{E. Parlouer}

Service Commun des Laboratoires, Strasbourg, France

\section{Pelaez}

Universidade Federal do Paraná, Paraná Institute of Technology (Tecpar), Brazil

\section{N. Pensel}

INTA, Instituto Nacional de Tecnología Agropecuaria, Argentina

\section{J.-P. Pinty}

Laboratoire d'Aérologie, Toulouse, France

\section{Pla}

Centre de Recerca en Agrigenòmica (CRAG), Barcelona, Sinstitute of Agro-Food Technology INTEA, Universitat de Girona, Girona, Spain

\section{Plan}

JRC-IHCP, European Commission Joint Research Centre, Institute for Health and Consumer Protection, Ispra, Italy

\section{Planchon}

CRA-W, Centre wallon de Recherches agronomiques, Unit of Biometry, Data processing and Agrometeorology, Belgium

\section{S. Poret}

Institut National de la Recherche Agronomique (INRA), Ivry-sur-Seine, and Ecole Polytechnique, Palaiseau, France

\section{E. Prantera}

ISS, National Institute of Health, Rome, Italy

\section{T.W. Prins}

RIKILT Wageningen UR, Wageningen, The

Netherlands

\section{J. Remacle}

EAT, Eppendorf Array Technologies SA, Namur, Belgium

\section{P. Richl}

Eurofins GeneScan GmbH, Freiburg, Germany

\section{R. Rocha dos Santos}

UNIBRASIL-QUIS, Paraná, Brazil 


\section{K. Rostohar}

Agricultural Institute of Slovenia, Ljubljana,

Slovenia

\section{R.B. Rud}

National Veterinary Institute, Oslo, Norway

\section{T. Ruttink}

ILVO, Institute for Agricultural and Fisheries Research, Merelbeke, Belgium

\section{Skjæret}

National Veterinary Institute, Oslo, Norway

\section{L-G. Soler}

Institut National de la Recherche Agronomique (INRA), Ivry sur Seine, France

\section{J. Soukup}

Department of Agroecology and Biometeorology, Faculty of Agrobiology Food and Natural Resources, Czech University of Life Sciences, Prague, Czech Republic

\section{G.R. Squire}

James Hutton Institute, Dundee, UK

\section{Stolze}

FiBL, Forschungsinstitut für Biologischen Landbau,Switzerland

\section{J. Šuštar-Vozlič}

Agricultural Institute of Slovenia, Ljubljana, Slovenia

M. Tachikawa

Ibaraki University, Ibaraki, Japan

\section{Tapia}

INTA, Instituto Nacional de Tecnología Agropecuaria, Argentina

\section{Taverniers}

Institute for Agricultural and Fisheries Research (ILVO), Technology and Food Sciences Unit, Merelbeke,

Belgium

\section{T. Tengs}

National Veterinary Institute, Oslo, Norway

\section{R.B. Tranter}

School of Agriculture, Policy and Development, University of Reading, Reading, UK

\section{S. Trapmann}

JRC-IRMM, European Commission Joint Research Centre, Institute for Reference Materials and Measurements, Geel, Belgium

\section{A. Trouillier}

Institut National de la Recherche Agronomique (INRA), Ivry sur Seine, France

\section{P. Tulet}

CNRM, Météo-France, Toulouse, France

G. Ujhelyi

RIKILT Wageningen UR, Wageningen, The

Netherlands

\section{H. Valdivia}

Laboratory of the Government Chemist, Analytical Technology, London, UK

M. Van den Bulcke

Scientific Institute of Public Health, Brussels, Belgium

\section{G. Van den Eede}

JRC-IHCP, European Commission Joint Research Centre, Institute for Health and Consumer Protection, Ispra, Italy

\section{J.P. van Dijk}

RIKILT Wageningen UR, Wageningen, The Netherlands

\section{J.C. Varela}

Centre de Recherche en Droit des Sciences et Techniques, Université Paris I, CNRS, Paris, France

\section{J. Vojvoda}

National Institute of Biology (NIB), Department of Biotechnology and Systems Biology, Ljubljana, Slovenia

\section{B. Vrščaj}

Agricultural Institute of Slovenia, Ljubljana, Slovenia 


\section{W.W. Wilson}

North Dakota State University, Department of Agribusiness and Applied Economics, Fargo, USA

\section{Wulff}

Eurofins GeneScan GmbH, Freiburg, Germany

L. Yang

Shanghai Jiao Tong University, Shanghai, China

\section{J. Žel}

National Institute of Biology (NIB), Department of

Biotechnology and Systems Biology, Ljubljana, Slovenia
Dabing Zhang

Shanghai Jiao Ton University, Shanghai, China

\section{David Zhang}

Groupe d'Etude et de contrôle des Variétés et Semences, laboratoire BIOGEVES, Le Magneraud, France

\section{Haibo Zhang}

National Veterinary Institute, Oslo, Norway; Shanghai Jiao Tong University, Shanghai, China

\section{M. Žnidaršič}

Jožef Stefan Institute, Ljubljana, Slovenia 


\section{Foreword}

In 1983, three reports from the University of Gent, the University of Washington, and the Monsanto Company showed that the Ti plasmid of Agrobacterium tumefaciens could be used to transfer foreign DNA into the plant genome, thus producing the first genetically modified (GM) plants. This discovery had enormous implications for plant genetics and agriculture. In the last 20 years, plant biotechnology has grown into a multi-billion dollar international industry while GMOs are cultivated on about 150 millions of hectares in around 25 countries.

Europe cultivates only a small amount of GM-crops (mainly GM-maize grown in Spain), though this is likely to increase in the future. This is particularly due to the European consumers' reluctance towards GM-derived foods. The freedom of choice of European consumers has been considered by the European Commission and the Member States through a legislative frame enabling the labelling of food and feed derived from, or consisting of, GMOs. In counterpart, the freedom of producers to grow either GMO, conventional or organic products is maintained by co-existence measures along the full supply chain, that is from seed production to the retailers' shelves.

To develop accurate product labelling and to determine a sustainable co-existence framework, several national and European research projects have been launched. The European research programs such as QPCRGMOFood and GMOChips focused first on GMO traceability and detection methods, then on co-existence issues with SIGMEA, Transcontainer and Co-Extra.

Co-Extra was for 4.5 years (2005-2009) the largest European research project on co-existence and traceability among supply chains. Co-Extra comprised 53 partners from 18 countries with more than 200 scientists with their teams. This program embraced technical, legal and socioeconomic issues, starting from seed production, with questions on the availability of non-GM varieties in the long-term, to the economic costs of traceability, with pollen flow studies and detection of unapproved GMOs as some examples of the work done. Numerous papers have already been published by Co-Extra while several more detailed deliverables are available from the website.

However, after such important research, it was thought necessary to present an overview of the work done and of the results obtained through the present book.

Several non-Co-Extra authors were also asked to provide us with a summary of the results of SIGMEA and Transcontainer, modelling results not studied in the project, traceability in non-European countries with labelling policies as well as their views on, for example, GMO-free areas. Indeed, Co-Extra results show that the operators use a practical threshold of $10 \%$ of the $0.9 \%$ legal labelling threshold. This changes the paradigm of co-existence, from a flexible co-existence scheme to a dedicated production area co-existence frame. Up to now, this co-existence scheme has not been completely finalised so that technical, legal, and societal questions remain unsolved.

It is thus my pleasure to introduce this book where numerous questions find solutions, even though several others remain.

To conclude this foreword, I would like to remind readers that all the issues covered by GM and non-GM supply chain co-existence and traceability have important applications in other food and feed chain traceability areas. For instance, the strategies for detecting unapproved and unknown GMOs may be used in clinical microbiology or biodefense while the increase in the accuracy of detection methods is useful in all other areas such as gene expression. In this way, the co-existence and traceability studies of GM and non-GM supply chains contribute to the improvement of both basic and applied research, as well as to the safety and quality of food chains.

Guy Riba

Vice-Chairman of Inra 


\section{Index}

Note: The suffix 'f' following a page locator indicates a figure, ' $n$ ' indicates a footnote and ' $\mathrm{t}$ ' indicates a table.

\section{A}

A. (Arthrocnemum) glaucum 276t

ABIOVE (Brazilian Association of Vegetable Oil Industries) 606

Abrange 91, 231, 232, 551, 554

absolute LOD/LOQ 310 see also limit of detection and limit of quantification

absolute LODs 343 see also limit of detection

Accent 120

acetyl CoA carboxilase $276 \mathrm{t}$

Achard, Carl-Franz 35, 36, 37

acyl-acyl carrier thioesterase $276 \mathrm{t}$

admixture see also adventitious GM presence

admixture function at drying 164

in the fresh potato chain $144 \mathrm{f}$

of GM and non-GM products 144 $170,210,227$

of GM and non-GM sugar beets 35 , 39

likelihood of 284

of non-GM products 171

pressure 172

threshold values 172

processes sensitive to admixture during supply chain 156

as a result of negligence 209

risk of 161

sources of 210

adventitious GM presence (AGMP) 53 , $55,56,57,58,161,205,256$, 260,265

farm-saved seeds 52

in OSR 50, 51

reduction of 28 regional model to assess 482

threshold on non-GMO land 581

Africa 287, 550, 622

North Africa 93

South Africa 4, 36, 230

Agreement Memorandum on Dispute Settlement 453 see alsoWorld Trade Organization

agricultural production 622 agriculture

agri-food safety management system in Korea 527-530

agricultural supply chains $\quad 622-623$

GMO-free 548-550, 625, 626, 627

industrialised agriculture 624

quality agriculture 549 see also quality signs

agronomic literature 210

alcohol 227, 582

alcohol dehydrogenase $1277 \mathrm{t}$

allergen labelling regulations 191

Amaranthaceae family $276 \mathrm{t}$

Amaranthus palmeri (Palmer's pigweed) 569

AM_DetQuant model 464, 466, 467f, $470 \mathrm{f}$

AM_DNAex model 464, 465, 465f, 466, $468 \mathrm{f}$

AMPE software 397

AmpliFluor 319, 320, 321

Amsterdam Treaty 439

analytical method model 463

anchor PCR 230

animal feed

GM soy in 253-255

labelling of 628

soybean products used in 215

animal feed manufacturers

production costs 221-222

segregation costs $220-223$ audits and analyses 222

benefits of 223-224

ingredient costs 220-221

total surplus cost 222-223

ANOVA tests 259,322

AOAC 385

AOC label 582, see also quality signs

apomixis 69-70, see also bioconfinement and biological containment

Appellate Body 450, 451, 452 see also World Trade Organization

apples 69, 441, 446

Apples case $441,442,446$

Arabidopsis 64, 65, 68, 69, 70, 73, 368

Arabidopsis thaliana 63, 379

Argentina 4, 216, 231, 237, 543, 545, 606

availability of non-GM soybean seeds in 89, 103-104, 109

certification in 612

costs and benefits of cultivating GM or non-GM soy 224-225

crop storage 147

demand for non-GM soybeans 109

equipment sharing 147

farming in 426

Flint maize chain identity preservation 151-152, see also supply chain segregation

food regulation 609,610

GM and non-GM planted areas in $91 \mathrm{f}$

importing of non-GM soybean seed from USA 146

intellectual property rights for plant breeders in 94

non-GM soybean seeds in 102-104, 108-109

number of GM and non-GM varieties for general use protected per year in $104 \mathrm{f}$

percentage share of soybean varieties registered in $103 \mathrm{f}$

Genetically Modified and Non-Genetically Modified Food Supply Chains: Co-Existence and Traceability, First Edition. Edited by Yves Bertheau. (C) 2013 Blackwell Publishing Ltd. Published 2013 by Blackwell Publishing Ltd. 
plant variety protection system in $95 \mathrm{t}$ production of non-GM soybeans in 94 RR soybean cultivation in 607 share of soybean harvest exported to the EU-27 606t

soy meal exported to the EU-27 606t soy oil exported to the EU-27 606t

soybean crushing 233

soybean production in 90,217 , 606-609

soybean seed breeding industry in 102f, 103

soybean seed purity 145

supply chains analysed $143 \mathrm{t}$

traceability requirements 610,614

arginine decarboxilase $276 \mathrm{t}$

Asia 521

see also East Asia

assays see reference assays and endogenous reference gene/ sequence

At1g53101 0 osr mapping probe 276t atmospheric model 81 see also Meso-NH Atriplex halimus $276 \mathrm{t}$

Atriplex hortensis $276 \mathrm{t}$

audits 217, 221, 222

Australia 4, 36, 229, 441, 595

Austria 9, 147, 155, 216f, 440, 554

ARGE Gentechnik-frei label 552

estimated production of compound feed $216 f$

land management in 549

automation potential, in GMO detection 324-327

auxotrophy 62

B

Brassica juncea (Indian mustard) 70

Bacillus thuringiensis 4

background pollen 25, 39, 40, 58 see also gene flow and pollen dispersal

barley 64

barnase $63,68,71$

BART (bioluminescent assay for real-time) detection system 335

see also LAMP-BART detection method

beans see soybeans

beef $229,231,424,434,528,530,545$, $548,550,552,553,596$

beet $29-30,501 \mathrm{t}$

characteristics of $24 \mathrm{t}$

co-existence in 30

cross-pollination between crops 29

ferals 30

fodder beet $276 \mathrm{t}$

garden beets $45,276 \mathrm{t}$ validated detection methods $501 \mathrm{t}$ volunteers 30

wild sea beet $30,37,41,45,281$

see also sugar beet, sea beet and Beta

Belgian Agency for the Safety of the Food Chain (FAVV-AFSCA) 217

Belgian compound feed, case study 215-241

Belgium

book of charge $217,218,236,237$

compound feed industry 187 , 215-241

consumption of feed ingredients in $216 \mathrm{f}$

facts and figures 215-217

Good Manufacturing Practices (GMP) 223, 224

legislative framework for GMO-controlled 217-218

production costs 221-222

segregation costs for the feed manufacturer 220-223

traceability and segregation at feed manufacturing level 219-220

traceability and segregation at import 218

cost calculations in single and compound food/feed value chains $179 \mathrm{t}$

costs of co-existence and segregation for compound feed production in 188

estimated production of compound feed $216 f$

Royal Decree 217

supply chains analysed $143 \mathrm{t}$

tomato supply chain 150

Bemefa 217, 218, 220

benefits, to farmers for cultivating GM crops 225

bestfordevelopment 466

bestforpurpose 465, 466, 469, 472, 474

Beta adanensis 37, 276t

Beta genus 276t, 281

Beta macrocarpa $36,37,276 \mathrm{t}$

Beta maritima 37, 276t see also sea beet

Beta patellaris $276 \mathrm{t}$

Beta patula Ait. $\quad 37,276 \mathrm{t}$

Beta vulgaris $29,36,37,276 \mathrm{t}, 281$ see also beet and sugar beet

Betula pendula (Birch) 63

between-increment relative standard deviation 251, 252-253 see also sampling

between-replicate analytical relative (standard) deviation 251, 252, 253, 254 see also sampling bias 322,328 see also measurement uncertainty

processing bias 314-315

of real-time PCR quantification 315-317

studies on 314

bias tests 303

bio-fuels 623

bioconfinement techniques 625,626 see also biological containment

BIOHAZ 446 see also European Food Safety Authority

biological containment see also bioconfinement

definition 61

and the relative position in the plant life cycle where they act $62 \mathrm{f}$

for transgenic crops $\quad 61-77$

bioluminescent assay for real-time (BART) detection system 335

see also LAMP-BART detection method

Biolytix 466, 469

Bioplex 353

Biotechnological Products Case 437, $439,440,443,444,451,453$

birch 63

biscuits 594

determination of GMO contents in 339

botanical genus 282

species 281

taxon 281

Bovine Spongiform Encephalopathy (BSE) $6,156,215,423,445,446,574$ $607,608,609,615$ see also TSE

bran $153,184 t, 611,613$

brand 122

Brassica napus 66

Brassica oleracea 66

Brassica rapa 28, 29, 31, 66, 73, 288

Brazil 4, 216, 217, 235, 426, 427, 543, $545,546-547,551,606,606 \mathrm{t}$

ABIOVE 606

ABRANGE 91, 231, 232, 551, 554

availability of non-GM soybean seeds in $89,101,110$

Biosafety Law 610

Brazilian Association of Vegetable Oil Industries (ABIOVE) 606

Brazilian Consumer Protection Code 610

case study on traceability and segregation of non-GM soy in 227

certification 612

chicken meat $\quad 152-153$

commercial liberation of GMOs and labelling issue in 609

demand for non-GM soybeans 109

EMBRAPA in $101,102,108,109,110$ 
equipment sharing 147

food regulation 609

GM and non-GM planted areas in $91 \mathrm{f}$ intellectual property rights for plant breeders in 94

MAPA (Brazilian Ministry of Agriculture, Livestock and Food Supply) 153

National Agency of Sanitary Inspection (ANVISA) 610

non-GM soy supply organisation 231

non-GM soybean seeds in 100-102, 109

number of GM and non-GM varieties registered in $102 \mathrm{f}$

percentage share of soybean varieties $101 \mathrm{f}$

plant variety protection system $95 \mathrm{t}$

production of non-GM soybeans in 93-94

registration of GM and non-GM varieties $102 \mathrm{f}$

RR (RoundUp Ready) soybeans in 607

share of soybean harvest exported to the EU-27 606t

soy meal exported to the EU-27 606

soy oil exported to the EU-27 606t

soybean breeding industry 101

soybean crushing 233

soybean IP system 151

soybean production in $90,419,547-$ 548, 606-609

soybean seeds 145,155

soybeans exported to EU-27 606t

supply chains analysed $143 \mathrm{t}$

traceability 610,614

and certification of non-GM soy and bran 611

Brazilian Association of Vegetable Oil Industries (ABIOVE) 606

Brazilian Consumer Protection Code 610

breeders, indifference to GMOs 424

Brevibacterium 513t

Britain see United Kingdom

Brittany 549-550 see also GMO-free European regional network

agricultural system in 546

GM and non-GM production in $547 \mathrm{t}$

see also France

broiler feed 221, $234 \mathrm{f}$

broiler hens 222, 228

BSE crisis see Bovine Spongiform Encephalopathy (BSE)

buffer zones 54,413 see also coexistence measures

bulk grains, sampling of 246-248 see also sampling

BUNGE 233, 613-614 cabbage 67

calibrants 391-393, 629

plasmidic reference materials as 535-536

Canada $35,36,426,521,537,543,551$, $555,583,596,602,606 \mathrm{t}$

cultivation of GM crops in 4,31

forest management in $570-571$

share of soybean harvest exported to the EU-27 606t

soy meal exported to the EU-27 606t soy oil exported to the EU-27 606t

soybeans exported to EU-27 606t

canola $4,31,297 f, 479,521,524,525$, 531

GM canola 538

see also oilseed rape and Brassica

CAP see Common Agricultural Policy (CAP)

capillary gel electrophoresis (CGE) 340

Cargill 233, 613, 614

Carrefour Group 425, 546, 552

carrot 65,67

Cartagena Protocol on Biosafety 8,411 , $522,531,534$

case specific monitoring (CSM) 11 see also post-market environmental monitoring

cattle $46,424,545,552,553,596$

cattle feed $155,215,234 \mathrm{f}, 426$

cattle feed manufacturers 162

CEC v. Ireland 444

CEC v. the Netherlands 444

cell-lethal gene expression 63

CEN Comité Européen de Normalisation see $\mathrm{CEN} / \mathrm{ISO}$ standard

CEN/ISO standard 9, 397

cereals 215

certification 612-613

GAP and environmentally-friendly $530 \mathrm{t}$

certified reference materials (CRMs) 390-393, 397, 423, 629

calibrants 391-393, 535-536, 629

mass-based certified reference material production 536

research and development of 526

CGE-LIF $340,342,343$

CGIAR see Consultative Group on International Agricultural Research

charters 583,585

cheese $424,548,549,551,582,583$

chicken dioxin crisis 156

feed 188

meat 222

meat supply chain $\quad 152-153$

broiler feed $234 \mathrm{f}$
China 4, 521, 538, 543, 606

Administration of Quality Supervision, Inspection and Quarantine (AQSIQ) 522

Administrative Measures on the Labelling of Agricultural GMOs 522

Administrative Measures on the Safety Assessment of Agricultural GMOs 522

Administrative Measures on the Safety of the Import of Agricultural GMOs 522

Administrative Regulation on the Biosafety of Agricultural GMOs 522

detection of GMOs in 524-526

event-specific detection methods for GMOs 525-526

GMO detection database 526

GMO labelling regulation 524

GMO production and processing regulations 523

GMO regulating authority 522

GMO regulation in $522-524$

GMO research regulations $\quad 522-523$

Ministry of Agriculture (MOA) 522

regulation on imports and exports 524

GM food 524

GM seeds and crops 524

regulatory framework for GMOs in $523 \mathrm{f}$

research and development of certified reference materials 526

risk assessment 523

sales of GM products regulations 523-524

salinity resistant Chinese wheat 420n

soybean crushers 233

State Council Regulation 523

chloroplast transformation $\quad 65-67 \quad s e e$ also bioconfinement and biological containment

hybridisation with wild relatives 66

plastid DNA transmission through pollen 65-66

transposition of chloroplast DNA to the nuclear genome $66-67$

chocolate 187

cost of co-existence and segregation for chocolate industry in Germany $188 \mathrm{f}$

costs calculations 186

GM ingredients in 180

choice experiment method $116-118,119 t$

citrus trees 69

cleistogamy $62,63-64,570$ see also bioconfinement and biological containment 
Club of Rome 623

clusters 579-580 see also coexistence cluster and dedicated production area

co-detection, likelihood of 284

co-existence $9-10,194,416$, 624-628

agro-ecological and co-existence issues 283

and agro-environment 584-585

in beet 30

benefits of 591-593, 602

and better environmental awareness 585

calculating costs of 190

clusters and 580 see also dedicated production area

co-existence issues of GM sugar beet 35-48

co-existence management strategies for grain merchants $128-134$

conditions 625-628

contract mechanisms to facilitate 595-602

and costs 628

costs of 602

dedicated production area $571-580$, 625

in East Asia 539

EC guidelines on 16

EU scenarios based on thresholds 564-566

EU scenarios resulting in spatial segregation 566-568

externality costs of co-existence without co-existence regulations 204-205

in the field 210, 255-256

of GM and non-GM food products, consumers' opinions and attitudes towards 115-126

between GM and non-GM supply chains, modelling and assessing the impacts of 161-175

of GMO and non-GMO crops

EU scenarios for $564-570$

European policy $563-589$

geographical implications of 563-589

in GMO and non-GMO supply chains 630

introduction to $3-20$

juridical nature of

freedom of choice by operators 417-419

and technological pluralism 416-417

limits and borders $568-569$

in maize $26,626-628$

management of 12 models and implementation of co-existence measures 29 50-52, 626-628

in oilseed rape $28-29$

policies $143,416-419$

regulation areas 209

regulations 205-209

segregated spaces and heavy checks 568

social benefits of 591-593

spatial modelling and geographical space $570-571$

strategies $\quad 150-155,156$

from farm level to export 15

identity preservation $150-151$

at processing level 153-155

in sugar beets, consequences of 42

in territories 580-585, 625

and traceability in supply chains 215-241

and traceability in the EU versus IP systems in third countries 605-616

co-existence policies $\quad 415-431,625-626$ national 418

Co-Extra project $\quad 3,10,189,249,267$, $274,300,315,326,372,388$

achievements of 461

analytical uncertainty 398 see also bias and traceability and GMO analysis and GMO detection

assessment of the modular approach in GMO analysis 295-303

analysis using RR soybean GTS-403-2 300

based on fuzzy logic assessment 301-302

extraction method and outcome of GMO analysis 297

module transfer parameters 302-303

PCR method efficiency and matrix influence 297-299

reference materials 299-300

technology equivalence 295-297

contractual purity threshold 86

database 488

DNA extraction 324

fuzzy logic assessment $301-302$

identification of benefits of introducing segregation and traceability systems 184

integration of Co-Extra results in EU tools for traceability $493-520$

method validation 397

organisation of 294

research conducted within 245

results on GMO sampling strategies in the food and feed chain 246-267

sampling in the field $246,255-257$ structure $294 \mathrm{f}$

study of strategies farmers used in order to ensure co-existence 151

see also decision support system (DSS)

co-liability 429

Coase theorem 205

Codex Alimentarius 7, 206, 236, 386, 397

COFFS traceability program 185,186

Cold War 550-554

collaborative trial results 395-396

collaborative validation of methods 386-387

collection silo model $\quad 128,129$

collection strategies see also territories

deliveries of GM and non-GM grain $132 \mathrm{f}$

deliveries per day for a collection with one product $132 \mathrm{f}$

farmer's choice model, variable values of $133 t$

grain merchant level

cost of 133-134

drying costs $133 \mathrm{f}, 134$

spatial strategy 134

transport costs $133 \mathrm{f}$

for landscape and product flow management, evaluation of 127-139

at the landscape level 134-135

farmer's choice model 134

input data and work hypotheses 134-135

spatial strategy 131-132, 136

temporal strategy 136

time strategy $132-133$

Commission Recommendation 2003/556/ EC 9, 178, 194, 206, 208, 497

Commission Recommendation 2004/787/ EC $9,246,248,268,273,293$, 497t, 498, 514

Commissioner of Health and Consumers' Protection (DG-SANCO) 8 615

commodity supply chains, empirical analysis of co-existence in 141-160

commodity supply contracts 426-428

Common Agricultural Policy (CAP) 421 , $423,554,555$

Common Catalogue of Varieties 289 communication campaigns 121

community litigation 449

Community Plant Variety Office 289

Community Reference Laboratory (CRL-GMFF) 497-499, 514, 515,516 see also EURL-GMFF 
commutability of reference materials 390-397 see also calibrant, CRM and reference materials compensation funds 208, 209, 412, 428, 429 see also redress, insurance and private insurance

complex food and feed products 186-189 complex materials, analysis of 317 compound feed industry 215-218, 233-236

cost of co-existence and segregation $188 \mathrm{t}$

costs and benefits

along the supply chain 224-230

elevators 225-226

at farm level 224-225

estimated production in the EU $216 \mathrm{f}$

European and Belgian compound feed industry 215-217

GM ingredients in 180-181

major stages in production $219 \mathrm{f}$

price evolutions of $234 \mathrm{f}$

compound food/feed products, costs of segregation and traceability between GM and non-GM supply chains of single crop and 177-191

conditional multinomial logit (MNL) model 117

confidence economy $419,422,423,430$

conflicts of interest 609,620

Consultative Group on International Agricultural Research (CGIAR) 286

consumer concerns $\quad 5-6,201-202$

consumer survey $118-120,189-190$

consumer trust $\quad 6,121$

consumers

attitudes towards GMOs in opinion polls 194-195

increased confidence in food products 229

opinions and attitudes towards co-existence of GM and non-GM food products $115-126$

opinions and attitudes towards GMOs 4-6

preferences regarding consumption of GM and non-GMO goods 592 , 593

proportions of different types of consumers $200 \mathrm{t}$

studies on consumer valuation of GM-free and GM foods 594

value of non-GM goods over GM goods 194-201

contracts $\quad 156,602,611-612$

control plans 254, 393-397

Conyza canadensis (horseweed) 569

COOPERL 546, 551 copy number ratios $300,303,391,392$, 397

core collections

GM target taxon 283-284

non-target taxa 283

recommended structure and content of 283-284

of reference assays for GMO quantification 280-289

corn $95,96,205,225,421,439,449$. 532,545

Bt corn $145,419,451,549$

corn products 533

cross-pollination 204

flow during wet-milling process 163

gluten feed, EU production of 216

GM corn 420, 607

GMO labelling $524 \mathrm{t}$

impurity rates in corn fields 206

landrace see Mexico

meal $524 \mathrm{t}$

non-GM 627

non-GM corn 229, 607

non-GM sulfonylurea herbicide-tolerant 42

oil 533

organic corn 449

PHF (post harvest free) corn 537

pollen 439,441

processing business 233

production in the USA 92

production of biodiesel 235

rootworm resistance 4

seed admixture 145

seed market 96

starch 193, 533

Starlink corn 235, 418

syrup 533

wild corn 420

see also maize

cornflakes $118 \mathrm{t}, 119,123 \mathrm{t}, 124$

Corollinae 36

costs

calculating costs of co-existence 190 co-existence and 628

commodity 184

cost-benefit analysis 591-595, 624

due to co-existence and segregation of food products 177

due to GM prevention measures 177

national differences in cost structures and calculations 189

of segregating wheat to conform to EU traceability standards $\quad 595-596$

of segregation and traceability between GM and non-GM supply chains of single crop and compound food/feed products 177-191

methodology 179-181

rapeseed results 181 results 181-189

single crop chains results $\quad 181-184$

transport 184

cotton 177, 230, 288, 343, 345f, 350,

374, 375f, 376f, 521, 525, 538

3006-210-23/281-24-236 Cotton 503t

Bt cotton 230, 440, 585

chloroplast transformation in 65

CRMs for GM cotton 526

cultivation of GM cotton 4, 531, 539

EU validated detection methods for 503t, 506t, 508-509t, 511t, 512t

event-specific detection methods for

GM cotton 525

GHB614 Cotton 509t

GMO labelling $524 \mathrm{t}$

LLCOTTON25 Cotton 506t

MON 531 Cotton 508t

MON 531 x MON 1445 Cotton 512t

MON 1445 Cotton 508t

MON 15985 Cotton 509t

MON 15985 x MON 1445 Cotton $511 \mathrm{t}$

MON 88913 Cotton $512 t$

screening table $373 \mathrm{f}$

seed meal, EU production of 216

credence goods 194, 201

crisp membership functions $301,302 \mathrm{f}$

critical field lengths, for measured outcrossing rates $262 \mathrm{f}$

critical levels

for demonstrating compliance with labelling thresholds 398

for demonstrating non-compliance with labelling thresholds 398

CRM ERM-BF413d 392

CRMs see certified reference materials (CRMs)

crop storage 147

cropping systems, interaction between landscape patterns and 59

crops, contributions of pollen and seed to impurities in 23-34

cross-pollination $31,79-87,146-147$, 204,255

in beet 29

decline with distance 25

factors affecting 25

in maize $25,79-87$

in oilseed rape $26-27,52$

upstream distribution 172

see also gene flow, pollen dispersal and pollination

cross-talk 340

cruciferine 276

crushers 228

crushing 149, 233

CTAB (Cethyl Tri-methyl Ammonium Bromide) method 318, 466, 469 see also DNA extraction 
Cucagna, Eduardo 104

cultivars 101

Cycling Probe Technology (CPT) probe 320, 321

cytoplasmic male sterility (CMS) 67 see also bioconfinement and biological containment

Czech Republic 178

estimated production of compound feed $216 f$

damage to property 407

damage to repair 428-429

Darwin, Charles, theory of natural selection 454

de la Blache, Paul Vidal 569

decision support system (DSS) 266, 303-304, 371, 372, 373 , $461-489,626,629$

AM_DetQuant model $464,465,466$, 470f

AM_DNAex model 464, 465, 465f, 466, $468 \mathrm{f}$

application of the transportation model 479-481

assessment of analytical methods 464-472, 487

assessment of processes $\quad 464,482-485$, 487

dryer model $\quad 483,484-485$

regional model (RM) 482-483

starch model 483

assessment of products 487

using traceability data $477-481$

assessment of sampling methods 472-477

bestfordevelopment assessment 466

bestforpurpose assessment 465, 466, $469,472,474$

characteristics of 462

components of 464

data-based (or data-driven) 462

database 464

and web-based implementation 485-487

dryer 464

EAT (Eppendorf Array Technology) DualChip 470f, 471f

fitforpurpose assessment 465

future of 488

goals of developing 487

model-based (or model-driven) 462

objective of 461

pentaplex-CGE $471 \mathrm{f}$

qPCR 35S 470f, 471f

qPCR lec1 470f

qPCR triplex 35S-lec1-IPC 470f, 471f regional model (RM) 464

sampling plans assessment 464

starch production process 464

transportation model 464, 478-479

UGM model 477-478

unapproved GMOs assessment of the potential presence of 464

see also Co-Extra project

decisions, control of the content of 449-450

dedicated production areas 571-580, 625 see also club, clusters, coexistence measures and flexible coexistence

spaces as controllable structures 571-572

DeKalb Pfizer Genetics 97

Denmark 28, 45, 121, 122, 123, 124 $147,181,182,183,187,188$, $216 f$

CEC v. Denmark 434, 435, 443, 444

co-existence costs for sugar beet supply chain in $183 \mathrm{f}$

compound feed case studies 187

cost calculations in single and compound food/feed value chains $179 \mathrm{t}$

cost of co-existence and segregation for compound feed production $188 \mathrm{t}$

cost of co-existence and segregation of wheat $181,595-596$

cost of co-existence and traceability of rapeseed oil $182 \mathrm{t}$

cost structure for producing non-GM wheat products at industry level 184

estimated production of compound feed $216 f$

risk of admixture on farms 147

sugar beet supply chain 145

supply chains analysed $143 \mathrm{t}$

detection method see DNA, digital array, digital PCR, PCR, GMO analysis and $\mathrm{GMO}$ detection

development risks 430

DEXi models $462-463,464,473,486$, 487 see decision support system

DEXi software 463 see decision support system

differentiation systems $180,185,186 \mathrm{t}$

digital array heatmap $313 \mathrm{f}$

digital PCR 391

combined with high-throughput nanofluidic PCR 311-313

dilution effect 172

Directive 90/219/EEC (also 1990/219/ EEC) 141

Directive 90/220/EEC (also 1990/220/ EEC) 141-142, 416
Directive 2001/18/EC 143, 178, 493, $495,496 \mathrm{t}$

Directive 2002/54 40

discrete choice analysis 117

extreme value type 1 distribution (EV1) 117

Dispute Settlement Body (DBS) of the WTO 434, 436, 437, 440, 442 see also World Trade Organization

disputes 9, 367

between GMO exporters and importers 614

settlement of 450

DMIF-GEN 10

DNA 142-143, 166, 279, 333

chloroplast DNA 65

detection 361 see also GMO analysis and GMO detection

ligation for detection of specific DNA sequences 357-358

plastid DNA 65

quantification methods 297f, 298

transmission of chloroplast DNA through hybridisation with wild relatives of OSR 66

DNA extraction 313 see also CTAB method

automation of $324-326,328$

from highly processed matrixes 317-318

manual and automatic 325-326

modules and DNA extracts, modular validation of 390

from oils 318

from soybean lecithin 318

DNA fingerprinting techniques 378

dryer model 130f, 131f, 483, 484-485, 487

assessment of 'Case 1' by $485 \mathrm{f}$

basic attributes for the $484 \mathrm{t}$

hierarchical structure of $484 \mathrm{f}$

plus-minus- 1 analysis $485 f$

test case for the 485

dryers 129

DSS sampling model 473 see also decision support system

DualChip GMO assay 387

microarray kit $346,347,348 f, 350$, 351,388

V2.0 $348-350$

report $351 \mathrm{f}-352$

duplex PCR 336-337

duplex QRT-PCR 339

Dupont de Nemours 421

E. coli dried killed bacterial biomass $512 \mathrm{t}$

East Asia, labelling and detection of GM crops and derived products in $521-541$ 
EC Product Liability Directive (PLD) 409

ECMWF model 81

economic literature 193, 199, 200t, 203

economic theory 193

EFSA (European Food Safety Authority) $5,7,8,11,142,369,436,445$, 446, 494, 619, 630

eggs $152,215,216,222,422,425,545$, 553,554

elevators 148

benefits of 226

costs 225

export elevators 226-227

soybean elevators 232-233

EMBRAPA 101, 102, 108, 109, 110

endogenous reference gene/sequence 278t, 524-525 see also reference assays

endosperms 166

enforcement costs 208

ENGL see European Network of GMO laboratories (ENGL)

ENTRANSFOOD 10

environment

damage to 406

harm to the 407

environmental issues 195

Environmental Liability Directive (ELD) 411

environmentally-friendly certification system, differences between GAP and 528, 530t

Eppendorf 298t see also decision support system and DualChip

equipment sharing 147

ERM-AD413 392 see also certified reference materials

estimated value 383

ethical issues 195

EURL-GMFF (European Reference laboratory for Genetically Modified Food and Feed) 273, $275,277,279,286,290,372$ 386, 38, 6297 see also CRL-GMFF

\section{Europe 4}

cultivation of GM crops in 543 demand for non-GM soybeans 92 dependence on imported soya 545-546

GMO-free regions network 544 maintaining a supply of non-GM feed in 543-562

opinions and attitudes of European citizens and consumers 4-6

soybean crushing 233

thresholds, indicating the presence of transgenic DNA $565 \mathrm{t}$ see also European Union (EU); specific countries

European Commission 127,161 , 415-416

co-existence policy 415

definition of the precautionary principle 433

research programmes $10-11$

European Commission Joint Research Centre (JRC) 518, 571 see also JRC

European Community (EC) 434

European Cooperative Programme for Plant Genetic Resources 288

European corn borer 4, 181

European cultivated potato database 288

European Environmental Council 415

European Feed Manufacturers Federation (FEFAC) 224

European Feed Manufacturers Guide 224

European Food Safety Authority (EFSA) $5,7,8,11,142,369,436,445$, 446, 494

European GMO-free regions network, declaration on labels and GM-free farming 10, 553-554, 625 see also GMO-free European Regions' network European Network of GMO Laboratories (ENGL) 8, 9, 10, 149, 273, 289, 290, 384, 386, 514, 515, $517,628,629$

and GMO analysis and validation 518

GMO analysis harmonisation and 497, 516

traceability of GMOs and 628

see also GMO analysis and validation

European Reference Laboratory for Genetically Modified Food and Feed (EURL-GMFF) $290 \mathrm{see}$ also EURL-GMFF and CRL-GMFF

European Regions' network see European GMO-free Regions Network

European Union (EU) 89, 115, 177, 237, $361,367,518,571,596$

arrival of GM soybeans in 3

attitudes towards GMOs in opinion polls 194-195

co-existence and traceability differences in Mercosur countries and 606

directives and regulations for risk assessment 7

food regulation 609

GMO-free regional networks 10

GMO/nonGMO labelling 193

harmonisation of GMO analysis 497-499 introduction of traceability and co-existence concepts into EU law 141-142

labelling regulations 193-194

objectives of legislation on GMOs 493

prevention strategy 191

production of soybean meal 216

recommendation on co-existence and economic criteria 620

regulatory framework 615 see also Commission Recommendation, directive and regulation

soybean imports into 216

support for GMO-free policies 553

traceability in Mercosur countries and 610-611

traceability of GMOs 193-194

traceability standards $\quad 595-596$

validated detection methods under Regulation (EC) No 1829/2003 500-513t

see also specific countries

European Union (EU) consumer behaviour study

attitudes towards locally produced foods 124

compensation 124

consumer behavior, attitudes and perceptions $120-121$

consumer survey $118-120$

consumer survey results 121-124

attitudes 122

food purchasing behavior 121-122

consumers' acceptance and WTP estimation 116

cornflakes, attitudes towards low carbohydrate 124

findings from the WTP analysis 122-124

literature review results $\quad 120-121$

opinions and attitudes of European citizens and consumers 4-6

qualitative and quantitative research methods 116

study methodology $\quad 116-120$

choice experiment method 116-118

survey procedure and response 120

willingness to pay a premium for organic food 123

see also consumers

European Union (EU) legislation

on food labelling 516

future challenges $\quad 499-518$

on GMO analysis 516

on GMO labelling 495

on GMO traceability 494-495

on GMOs 493-495

on seeds 516

see also Commission Recommendation, directive and regulation 
European Union Reference Laboratory for Genetically Modified Food and Feed (EURL-GMFF) 290, 386 see also EURL-GMFF and CRL-GMFF

expertise 619-622

and counter-expertise 621

rejection of 621

export elevators 226-227

benefits of 226-227

costs 226

F

FAO (Food and Agriculture Organization of the United Nations) 385

Treaty on phyto-genetic resources $420 \mathrm{n}$

farm production 623

farm-saved seed production $\quad 421-422$

farmer penalties 601

farmers 622

choice of GM or non-GM crops 624

farmer's choice model

spatial strategy 135

time strategy 135

fault liability 409

feed, European directive on botanical impurities in 5

feed industry, labelling rules 237

feeding the world $623-624$

feedstuffs, market for 215

LLP see GMOs Low Level Presence

FEFAC see European Feed Manufacturers Federation

ferals, oilseed rape ferals 28

Feria de Norte Semillas 104

field experiments, and data collection 256-257

Finland 410

estimated production of compound feed $216 f$

fish, suspension of fish marketing approval and stock destruction 448

FitForPurpose 474

FitForScreening 463

decision rules 463

fitness-for-purpose 383,466

flexible coexistence 26, 29, 625 see also coexistence, clusters and dedicated production area

flour $162,184 \mathrm{t}, 255,268,410,425$, $524 \mathrm{t}$

analysis of $255 t$

cost and performance of control plans $254 \mathrm{t}$

Danish production study 183

maize $162,296 \mathrm{f}, 374$

soybean 233, 247, 248, 249, 253

wheat $179 t, 180,182$ flowering inhibition 63 see also bioconfinement and biological containment

and complete sterility $\quad 62-63$

flowering plants

asexual reproduction 69

sexual propagation in 69

Fluidigm's BioMark 312

fluorescent beads, and flow cytometry 353

fodder beet 276t see also beet, Beta and sugar beet

food and feed chains, GMO sampling strategies in $245-272$

food crises 623

food industry, new technologies in 115

food market, changes in safety and quality requirements 607-609

food preference studies 594

food regulation $142,609-610$

food safety 142

FP6 Co-Extra project 10,328

France $35,190,564,592 \mathrm{n}, 593,626,627$

AOC label 582, 586

approval of a GMO release for experimental targets 435

average surface area of farms in 622

beet crops in 29

Charte de l'Environmement 433

charters for regional national parks 585

Clermont-Ferrand Court 449

clusters in 586

Conseil d'Etat 441

cross-pollination of maize study $80-81$

economic, ethical and social committee (CEES) 620

effect of BSE crisis 607

estimated production of compound feed $216 f$

French Conseil d'État 441

gene flow in beet studies 43

GMO-free agriculture 548-549

GMO-free labelling threshold 153

GMO-free labels 552

imports 149

INAO 572,582

initiatives in $577-578$

local councillors in 572

model for determining co-existence measures 626

oilseed rape seeds 145

quality labels 572

research programmes 10

sugar beet in 42

sugar beet production systems 44

sugar beet seed production areas in 40

supply chains analysed 143

territories $\quad 572-574$ thresholds, indicating the presence of transgenic DNA $565 \mathrm{t}$

see also Brittany

freedom of choice

by consumers and producers $5,6,9$, $10,543,624,625$

by operators 9,417-419

freedom of trade and industry 417 , 418

fruit, parthenocarpy $\quad 68-69$ see also bioconfinement and biological containment

fuzzy logic assessment 301-302

based indicators $300,385,397$

GAFTA, Recommended Terms and Conditions of Business 1999 428 see also Grain and Free Trade Association

game-theoretic model $595,596-597$

base case data and assumptions used in the P-A problem 598t

GAP (good agricultural practices) 527, $530,532,533$

and environment-friendly certification system 528, 530t

garden beet 45, 276t see also beet, Beta and sugar beet

GATT 550 see also World Trade Organization

Gemma proficiency test scheme 394 gene flow $31,32,79-88,194,205,255$, 626

in beets $35,42-43$

between GM and non-GM fields 206

in maize $24 \mathrm{t}, 26,80-83$

in oilseed rape $49-60$

prediction of 43

see also cross-pollination, pollen dispersal and pollination

gene stacking 26, 333, 335, 369, 371, 624

General Food Law see Regulation (EC) No 178/2002/EC

GENESYS model 55,56

GENESYS-Beet model 43

oilseed rape volunteers $50,51 \mathrm{f}$

genetic resources 420

Genetic Use Restriction Technologies (GURTs) 70,625 see also bioconfinement, biological containment, T-GURT, and V-GURT

genetically modified organisms see GMOs

genomic DNA (gDNA) 300, 392

geographic information system (GIS) software 256, 257, 627 
geographical spaces 569,586

discontinuities that cannot be controlled by people $569-570$

made up of territories that are all social constructions $\quad 572-574$

spatial modelling and 570-57

see also dedicated production area and territories

Germany $10,35,182,184,189,571$, $592 \mathrm{n}$

co-existence costs for sugar beet supply chain in $183 \mathrm{f}$

cost calculations in single and compound food/feed value chains $179 t$

cost for non-GM food production in supply chains in $185 \mathrm{f}$

cost of co-existence and segregation for chocolate industry in $188 \mathrm{f}$

cost of co-existence and segregation of wheat 181

cost of co-existence and traceability of rapeseed oil $182 \mathrm{t}$

cost structure for producing non-GM wheat products at industry level $184 \mathrm{t}$

crushing of soybean, maize and oilseed rape 149

estimated production of compound feed $216 f$

GMO-free regulations 552

imports from outside the EU 149

oilseed rape seeds 145

pest management 181

supply chains analysed $143 \mathrm{t}$

wheat starch supply chain 183

germplasm 95-111, 281-287 see also genetic resources

Germplasm Resources Information Network 288

GIS see geographic information system global conferences 517

global development and consumption model 623

$S$-glucosyl transferase $276 \mathrm{t}$

glyphosate $38,39,93,231,569$ see also Roundup

GM adventitious presence quantification 127, 166-167, 168

distribution in the non-GM harves $169 \mathrm{f}$

in non-GM field harvests $167,170 t$

GM animals 369

GM content, estimation as percentage of DNA bearing the transgene 166

GM crops

benefits of 190

cultivation of 4

post-market environmental monitoring $3,4,7,8,11,630$
GM detection methods, employing ligation detection $359 t$

GM farming, general public's fear of potential risks of 405

GM food products, consumers' opinions and attitudes towards non-GM and $115-126$

GM food valuation studies

proportions of different types of consumers 200t

WTP for non-GM products $198-199 t$

GM foods, safety assessment and labelling policy in Japan 534

GM microorganisms (GMMOs) 369,548

GM plants 543

endogenous reference gene systems for detection of 524-525

increase in growth of 177

GM products, segregation strategies of non-GM and 154

GM quantifications, mean and variance normalised values for 323

GM soy, price evolutions of $234 \mathrm{f}$

GM supply chains, introduction to non-GM and GM supply chain co-existence and traceability $3-20$

GM target taxon 281-282 see also GM plants, reference assays and endogenous reference assays

borders of 284

definition in relation to botanical taxa $282 \mathrm{f}$

GMO analysis

accurate determination of the limit of detection 308-309

analytical result interpretation 515-516

analytical template $266 \mathrm{f}$

Co-Extra assessment of the modular approach in 295-303 see also modular approach

costs for 222

'Detecting GMOs' interactive DVD 517

EU harmonisation of 497-499

extraction method 297

global capacity building on 516-517 see also Cartagena protocol

global conference on 517

global harmonisation $\quad 516-518$

global networking on 517-518

new methods to be validated 514-515

overview of the strategies for the highthroughput $336 f$

qualitative oligoplex PCR-CGE reported for $344 \mathrm{t}$

sampling harmonisation $\quad 499-514$

strategies for high-throughput 334-335

training material 517

User Manual 517 see also GM content, GM plants and GMO detection

GMO crops, geographical approach to the European policy for the co-existence of non-GMO and 563-589

GMO detection

analysis of a complex sample with mixed ingredients and processed material $376-377 \mathrm{f}$

development and harmonisation of 518

differential quantitative PCR 379,629 see also unauthorised GMOs

evaluation of automation potential in 324-327

justification of the need for more efficient and cost effective strategies for 333-334

matrix approach $372,373,629$ see also unauthorised GMOs

new multiplexing tools for reliable 333-365

review of $371-378$

single low processed ingredient 374 $375 f$

unit see haploid genome equivalent see also GMO analysis, collaborative trial, collaborative validation of methods, single lab validation and screening

GMO detection database 526

GMO-free

agriculture 548-550

dedicated production areas 625

foods, consumer valuation of 593-595

labels 237

land management 549

thresholds 626,627

GMO-free European Regions Network $232,544,545$

business meeting 551

conference 551

goals of 544

roll-back policy $551-552$

working groups 544

GMO labelling threshold $\quad 8-10,190$

GMO laboratory sample output

assessing validity of procedures from test portions from laboratory samples 266-267

impacts of measurement uncertainty on 'real world' actions or decision 266-267

GMO quantification, reliability of 313-317 see also GMO analysis and $\mathrm{GMO}$ detection

GMO sampling strategies

in fields 246, 255-259, 626, 627 
in food and feed chains 245-272 conclusions and future perspectives 265-266

general aspects and software tools for sample size determination 248-249

during production and distribution 248-255

sampling uncertainty 267,268

see also sampling

GMO test methods, validation of 294 295, $296 \mathrm{f}$ see also validation

GMO testing 304, 514 see also GMO analysis and GMO detection

GMOChips European research project 346,372

GMO

assessment of health and environmenta risks related to 619

attitudes of consumers in opinion polls towards 4-6, 194-195, 621

banning of 200

classifications relevant to detection 368-371

coexistence see coexistence, dedicated production area, flexible coexistence and territories

detection unit see haploid genome equivalent

detection database 526

detection of unknown GMOs 367-382 see also unauthorised GMOs

determination of attitudes towards 4-6, 195-197, 621

development of 3-4, 367

and standardisation of event-specific detection methods for 525-526

expertise of 619-622

and counter-expertise 621

rejection of 621

externality costs of co-existence without co-existence regulations 204-205

feed and indifference to 424

fully characterised 370

gene-stacked 371

and genetic resources 625

and harm to the environment $7,8,10$, $11,407,619,623,630$

harmonised control analysis 293-294

knowledge based classification of 369-371 see also unauthorized GMOs

knowledge class 1370

knowledge class 2 370-371

knowledge class $3 \quad 371$

knowledge class $4 \quad 371$

known GMOs 367

labelling and co-existence regulation of non-GMOs and 193-214 see also labelling and threshold legal classification of $\quad 368-369$

liability and redress options for damage caused by GMOs 405-413

low level presence (LLP) of unapproved GMOs 236, 369, 422, 538, 549,629

management of co-existence and traceability of 12 see also coexistence and traceability

market authorisations of 619

new production methods 629

novel characteristics of 367-368

opposition to $202,209,415,619$

personal injury and damage to property 406-409

prevention of future harm 406

and pure economic loss 407-408

reliability and cost of detection of 307-332

risk perception 6-7, 619-621

sample analysis, technology equivalence 295-297

special liability regimes 409

spread by pollen 584 see also gene flow and pollen dispersal

transformed with new combinations of genetic elements 371

transformed with the same genetic construct(s) as GMOs in knowledge class $1 \quad 370-371$

Good Manufacturing Practices (GMP) $223,224,369,370 f, 413$

good practices of GM and non-GM production 413

government of techniques 416,417

Grain and Feed Trade Association (GAFTA) 427, 428

grain merchant

collection strategies 131-134

cost of different management strategies 133-134

evaluation of co-existence managemen strategies for 128-134

evaluation of collection strategies farmer's choice model 133t, 134

input data and work hypotheses 131t, 134-135

at the landscape level 134-135

run of the simulation model $129-131$

segregation strategies 131t, 135-136 see also coexistence

allocation of GM and non-GM varieties $137 \mathrm{f}$

spatial strategy $136 \mathrm{f}$

simulation model 128-13

spatial strategy $130,131-132$

time strategy $130,132-133$

transport 128-129

grains 605

see also barley; corn; maize; wheat granular-sampling relative standard deviation 253 see also sampling

Great Britain see United Kingdom

Growth Hormone case 437, 439, 440, 442, 446

GURT see bioconfinement, biological containment, Gene Use Restriction Technology, Terminator, T-GURT and V-GURT

HACCP $127,223,224,425,427,527$. $528,532,533$

Haeckel, Ernst 569

Hamilton Microlab Star Liquid Handling station 326

haploid genome equivalent (HGE) 8, $273,303,314,333,347,391$, $516,626,627$

hard identity preservation programme 218 see also identity preservation

hard red spring wheat 597

harvest discarding 54

HEAR segregation system $185,186 t$

Helms, Ted 100

hens

broiler hens 222,228

layer hen feed $234 \mathrm{f}$

herbicide resistance, in sugar beet 44

herbicides 231

sensitivity to 61

see also glyphosate

Herfindahl-Hirschman Index (HHI) 96, 97, 101, 103

hexa(6)-plex PCR-CGE-LIF 344t

hexa(6)-plex PCR-CGE-SC 344t

hexaplex PCR 343

HGE see haploid genome equivalent

Hi-Pro-soybean meal 215

high grade multiplex strategies 357-36

high mobility group protein $276 \mathrm{t}, 277 \mathrm{t}$

Holland see the Netherlands

hormone case see growth hormone case horseweed 569

human resources $574,576 \mathrm{t}$

humans, damage to 406

Hungary 554

estimated production of compound feed

hygiene practices 224

identity preservation $150-151,156,205$, 602,614

of IP corn rose 608

programme 152

see also coexistence and segregation

identity preserved production and marketing programmes (IPPM) 150 
identity preserved products 204

IMCOPA 227, 232

imports 148-149

impurities, determination of 273

in-house validation 338,385 see also collaborative trial, GMO analysis, GMO detection and validation

incentive premiums, required for contracting strategy 600f, 601f

India $36,230,232,236,338,521,551$. $553,554,555,606$

GMO cultivation in 4

production of non-GM soy $91,92 \mathrm{t}$

Indian mustard 70

ingredients $279 \mathrm{t}, 281$

cost of 220

insects, resistant 630

insurance 411-412

private insurance 411-412

social insurance 411

see also compensation and redress

intangible resources $574,576 \mathrm{t}$

intellectual property rights $89,90,98$, 106

intellectual property rights for plant breeders 94, 110 see also farm saved seeds

inter-laboratory studies $\quad 386-387$ see also collaborative trial and validation

internal positive control (IPC) 316, 317t, 334,340 see also DNA extraction

international case law 434

International Federation of Inspection Agencies (IFIA) 428

International Rice Research Institute (IRRI) 288

International Seed Testing Association (ISTA) 514

International Standard Organization (ISO) 386 see also CEN/ISO standards

international trade, in agricultural products 622

International Union for the Protection of New Varieties of Plants (UPOV) 94, 289

International Workshops on harmonisation of GMO Detection and Analysis 517-518

interviews with stakeholders 141

invertase $277 \mathrm{t}, 346$

IPRs (intellectual property rights) 98

Ireland 37, 554

CEC v. Ireland 444

estimated production of compound feed $216 \mathrm{f}$

GMO-free Ireland Network 552-553

IRRI see International Rice Research Institute
ISBA model 81

ISTA see International Seed Testing Association

ISO/CEN standards 9, 397 see also CEN/ISO standards

isocytosine 319

Italy $26,29,40,45,145,215,546,547$, $548,549,583$

estimated production of compound feed $216 f$

IUPAC 385

$\mathrm{J}$

Japan $521,522,534-538,596$ agricultural products case 444 apples case 446

changes in the soybean and maize supply chains in response to GMO labelling 536-538 demand for non-GM soybeans 92 development of detection methods 534-535

development of plasmidic reference materials as calibrants $535-536$ impact of GM labelling in 538 labelling system in $535 \mathrm{t}$ maize supply chain $\quad 537-538$

mass-based certified reference material production 536

safety assessment and labelling policy for GM foods in 534

soybean supply chain 537

standard detection methods 534-536

Joint Research Centre (JRC) 516, 614 629

JRC-IHCP (Institute for Health and Consumer Protection) 8, 290 see also EURL-GMFF and CRL-GMFF

JRC-IRMM (Institute for Reference Materials and Measurements) 299, 304, 629 see also CRMs

judgement proof 208

judges 433

as arbitrators of scientific assessments 447-454

deeper judicial control 451-454

guide to administrative action 434-447

restrained control 447

role concerning science in precautionary measures 433-457

thorough control 447

venturing into scientific fields 451-452 jurisprudence $433,437,452$

K

k-nearest neighbour (k-NN) algorithm 259

KELDA project 246 see also GMO sampling strategies and sampling
KeSTE software 249 see also GMO sampling strategies and sampling

KingFisher Flex 325

known GMOs 367 see also unauthorised GMOs

Korea 521, 522, 527-532

agri-food safety management system 527-530

control of agricultural raw materials 532

control of feed 532

detection of GMOs in 531-532

differences between GAP and an environment-friendly certification system 528, 530t

Korea Food and Drug Administration (KFDA) 531

living modified organisms 531

management system of agricultural and fishery LMOs in $527 \mathrm{f}$

Ministry for Food, Agriculture, Forestry and Fisheries (MIFAFF) 531

National Agricultural Products Quality Management Service (NAQS) 531

regulatory framework of GMOs in 531

statutory compulsory certification system 528

statutory optional certification and mark system $528,529 t$

labelling $6,127,150,178,190,201-204$ 422, 624 see also threshold

benefits of 185

and consumer concerns 201-202

EU legislation on 495

exemption from labelling requirements 495

of feed products 154

GMO-free labels 237, 625-627

of GMOs in Japan 536-538

implementing traceability and labelling policy 202-204

mandatory labelling of GM goods 203

regulations 249,524

retailers, consumers and 228-229

and traceability strategies $230-236$

thresholds $8-10,626,627,629$

voluntary labelling of non-GM goods 203

Labelling and Traceability Regulation see Regulation (EC) No 1830/2003 and Regulation (EC) No $1829 / 2003$

labels

AOC label 582 see also Quality signs ARGE Gentechnik-frei label 552 see also GMO-free

GMO-free labels 237, 625-627

technology label 293 
labels of origin 424, 572 see also Quality signs

lamb 552

LAMP-BART detection method 471, 472

Lancaster consumer theory 116

land management 549

Register 418

structure 568

use $571,581,582$

see also geographical spaces and territories,

landscape

and product flow management,

evaluation of collection strategies 127-139

patterns, interaction between cropping systems and 59

long-distance pollen flow in large fragmented landscapes $\quad 79-88$

see also gene flow and pollen dispersal

laser induced fluorescence (LIF) 340

lateral flow device (LFD) 470f, 471, 472 see also GMO detection

Latin America 178, 287, 426, 479, 612, 613,622

see also Argentina; Brazil; Mercosur countries; Paraguay; South America; Uruguay

law of the Alliance 416

LCR see ligase Chain Reaction

leaf beet 276t see also beet, Beta and sugar-beet

lecithin 318

legal appraisal $\quad 452-454$

legal intervention 206-207

legal issues, co-existence policies $\quad 415-431$

LFD see lateral flow device

liability $9,10,194,205,207,237,407$, $408,416,417,428$

for adventitious GMO presence above labelling threshold 210

environmental liability 411

for fault versus no-fault liability 429

individuals who are liable 429-430

Member States' liability 429

product liability 409-411

and redress options for damage caused by GMOs 405-413

of small operators 430

strict liability rules 409

see also compensation, insurance and redress

ligase chain reaction (LCR) 357-358 see also SNPlex

ligation 361-362

and PCR-based strategies 356-361

amplification reaction (LAR) 358

-dependent probe amplification (LPA) $358,359 \mathrm{t}$

detection reaction (LDR) 358 limit of detection (LOD) 308-309, 310, 343,384

limit of quantification (LOQ) 310-313

definition of 310

linearity 384

link target taxon species 279 see also reference assays and endogenous reference gene/system

taxon ingredient 279

Listeria bacteria 450

litigation 208

community litigation 449

control of the content of decisions $449-450$

national and European $\quad 448-449$

precautionary principle 448

LLP seelow level presence and feedstuff

LMOs (living GMOs) 527f, 531-532, 534, 548 see also Cartagena protocol

Lo-Pro soybean meal 215

locked nuclei acid (LNA) probe 320 , 321,328

LOD see limit of detection (LOD)

loop-mediated isothermal amplification (LAMP) strategy 335

LOQ see limit of quantification (LOQ)

losses, linked to GMOs 408

low level presence (LLP) of unapproved GMOs $236,369,422,538$, 549,629

Luminex X-map technology 378

Lux technology 319

Luxembourg 410

M

Maastricht Treaty 293

maize $23-26,162,215,274,276 \mathrm{t}$

$10 \mathrm{kDa}$ zein $277 \mathrm{t}$

1507 (TC 1507) maize 500

$1507 \times 59122$ maize $504 \mathrm{t}$

1507 x NK603 maize 501t

3272 maize $510 \mathrm{t}$

59122 maize $501 \mathrm{t}$

59122 x 1507 x NK603 maize $507 t$

$59122 \times$ NK603 maize $508 \mathrm{t}$

analysis of single ingredient sample of $375-376 \mathrm{f}$

Bt maize $4,127,178,181,500 t$, 585

Bt10 maize 500t

Bt11 field maize 506

Bt11 maize 509t

Bt11 sweet maize $500 t$

Bt11 x GA21 maize 510t

CBH351 (Starlink) maize 368

characteristics of $24 \mathrm{t}$

co-existence in 26

co-existence model $\quad 626-627$ cost calculations in single and compound food/feed value chains $179 \mathrm{t}$

cross-pollination 25

long-distance $\quad 80-81$

and volunteers 146

crushing 149

DNA quantification methods

maize feed $298 \mathrm{t}$

maize grain 298

maize tortilla $298 \mathrm{t}$

effect of volunteers on GM content in non-transgenic maize yields 263-265

estimation of the contribution of GM volunteers to the GMO percentage in the yield of a conventional field 265

evaluation of the proportion of volunteers that reached the flowering stage 264-265

field sown with conventional maize showing GM volunteer plants $263 \mathrm{f}$

Flint maize chain identity preservation 151-152

flour 162, 296f, 374

forage maize 162

GA21 maize 500t, 507t

germplasm 287

GMO detection in $374,375 f$

GMO maize cultivation 625

grain maize 162,181

growth of GM maize 178

landrace 26, 625

long-distance dissemination $26,79-87$, 626

LY038 Maize 510t

maize area fraction and accumulated deposition of viable pollen grains 84,87

male-sterile cytoplasm 67

map of maize fields over the Landes region in Aquitane region 82-83

MAPOD model $134,163,167,626$

Mexico 625

MIR 604 maize 506

modelling of pollen flow $626-627$

MON 810 maize $512 \mathrm{t}$

MON 863 x MON 810 x NK603 maize $503 \mathrm{t}$

MON 863 x MON810 maize $502 t$

MON 863 x NK603 maize $502 t$

MON 89034 maize $510 t$

MON 89034 x 88017 maize $513 t$

MON 89034 x NK603 maize 513t

Mon863 maize 500t

MON88017 maize $509 t$

MON88017 x MON810 maize $513 t$ 
NK603 maize 500t

NK603 x MON 819 maize $502 t$

oil, DNA extraction from 318

outlets for maize grain 162

PCR-CGE-SC method for detection of target sequences in $345 \mathrm{f}$

PCR methods for detection of GM 525

pollen dispersal $79,568,626$

pollen viability $83,84 \mathrm{f}$

potential for crossing and introgression $24 \mathrm{t}$

record of volunteer density in agricultural fields 264

reference assays $275,277 \mathrm{t}$

$10 \mathrm{kDa}$ zein 343

alcohol dehydrogenase 1 gene $277 \mathrm{t}$

invertase gene $277 \mathrm{t}$

starch synthase gene $277 \mathrm{t}$

screening table $373 \mathrm{f}$

seed price $133 \mathrm{t}$

seed production 626

simulated pollen viability $84,86 f$

simulated regional pollen dispersal 84 , $85 f$

starch maize 181

starch maize supply chain $185 \mathrm{f}$

Starlink maize 368 see also $\mathrm{CBH} 351$ maize

storage of 152

supply chain

GMO labelling 536-538

in Japan 537-538

supply chains and regions analysed

T25 Maize 501t

transgenic maize Case 447

transport $481 \mathrm{f}$

transport and reloading of 148

transport costs $133 \mathrm{t}$

treatment $133 \mathrm{t}$

use in the US 623

validated detection methods under Regulation (EC) No 1829/2003 500-501t, 502-503t

vertical variations in maize pollen concentration 83

volunteers and ferals in 26

white-kernel maize $79,80-81,85$

long-distance cross-pollination study $80-8$

yield rate $133 \mathrm{t}$

see also corn; grain merchants; grains

Malaysia 36

male sterility

cytoplasmic male sterility (CMS) 67

engineered male sterility $\quad 67-68$

monogermy 41

Owen cytoplasm 41

ribonuclease/barnase expression 68

split barnase 68 see also bioconfinement and biologica containment

mango 69

MAPOD model 134, 163, 167, 626 see also maize and coexistence

Marggraf, Andreas Sigismund 36

market-based initiatives $\quad 577-578$

marketing 603

Maroilles cheese 582

Martin, Steve St 100, 106

material resources $574,576 \mathrm{t}$

matrix approach 336, 372-374, 379 see also quantitative differential PCR and unauthorised GMOs

measurement uncertainty $255,265,266$, $267,307,387,391,393-397$, $398,515-516,627$

effect on assurance and enforcement of labelling 396-397

estimation using collaborative trial results 395-396

estimation using proficiency test results 394-395

see also analytical uncertainty, bias and sampling

meat $152,210,215,222,223,237,422$, $423,424,549$

BSE animal-infected 446 see also TSE consumption 4,607

demand for 216

GMO-free 552, 553, 554, 595

hygiene package and GMO Regulation $178 / 2002608$

organic 223

prices 231

segregation during BSE crisis 156

see also beef; chicken meat; pork; veal

Mediterranean corn borer (Sesamia nonagrioides) 4

Mercosur countries

co-existence and traceability differences in $\mathrm{EU}$ and 606

food regulation 609-610

GM soybeans in 606-609

regulatory framework 615

traceability in EU and 610-611

see also Argentina; Brazil; Paraguay; Third countries; Uruguay

Meso-NH model 79,81 see also crosspollination, gene flow and pollen dispersal

method validation, and reference materials 383-401

Mexico

contamination of Mexican wild corn varieties 420

GMO maize cultivation $\quad 625$

See also maize landraces

microarray technology 387
Middle East $\quad 37,93,550$

Milanesi, Leonardo 108

milk

powdered milk 550

rBST (recombinant Bovine SomatoTropin) milk 203

soybean milk $298 \mathrm{t}$

Ministry for Food, Agriculture, Forestry and Fisheries (MIFAFF) 529t

Minor Groove Binding probe 320

mixed Nash equilibrium $599,600,601$

MNL see conditional multinomial ogit model

modelling 162 see also atmospheric model, coexistence, gene flow, GENESYS, MAPOD, meso-NH, pollen and software

modular approach 304, 397 see also GMO analysis and GMO detection

module transfer parameters 302-303

molecular beacons (MB) 320, 321

Monsanto 95

Monsoy 101

most probable number (MPN) 310-311, $328,334,339,388,539$

MPN see most probabe number

Muller, Pierre 621

multiple displacement amplification DNA (mdaDNA) 300, 392

(MDA) strategy 335

multiple oligoplex reactions in a single CGE-SC run 344-346

multiplex assays 387

GMO detection methods 334,371 , 374-378

LPA (MLPA) 358

methods 372

PCR 336, 337

universal PCR and array based detection $347 f$

mycotoxins 247,268 see also sampling

Nanae 36 see also beet, Beta and sugar-beet

Nanodrop 298t

NASBA (nucleic acids based amplification) implemented microarray analysis (NAIMA) 335, 353-356, 378

applicability and cost 354-355

future use of $356-357$

performance 355

principle $353-354,354 \mathrm{f}$

properties of $355 \mathrm{t}$

Nash equilibrium, mixed $599,600,601$

National Institute of Metrology, Normalisation and Quality Control (INMETRO) 612 
national references laboratories (NRL) 8, 498, 499 see also Regulation (EC) $882 / 2004$

near infrared (NIR) spectra/spectroscopy 335, 356 see also GMO analysis and $\mathrm{GMO}$ detection

negative PCR products 629 see also GMO-free

the Netherlands $103,197,215,216 f$ $289,553,594$

CEC $v$. the Netherlands $437,438,439$, $443,444,445$

estimated production of compound feed $216 f$

Nidera Semillas S.A. 101f, 102f, 103

Nigeria 36

see also Africa

non-GM feed 543-562 see also GMO-free

containment 550

roll-back $550-551$

non-GM food, demand for 229

non-GM food products, consumers' opinions and attitudes towards GM and 115-126

non-GM soy 547

price evolutions of $235 \mathrm{f}$

non-GM supply chains, introduction to GM and non-GM supply chain co-existence and traceability $3-20$

Non-GMO and Organic Report 93

non-GMO crops, geographical approach to the European policy for the co-existence of GMO and 563-589

non-GMOs, labelling and co-existence regulation of GMOs ans 193-214

non-market based initiatives $\quad 577-578$ non-PCR methods 353-356

comparison to real-time PCR 355

non-target taxon 282 see also general surveillance, GM crops and postmarket environmental monitoring

nona(9)-plex PCR-CGE-SC 344t

North American wheat 595 see also wheat

Norway 410, 606t, 619

soy meal imported to the EU-27 606t

soy oil imported to the EU-27 606t

Svalbard Global Seed Vault 420n

novel food and novel ingredient law 178 see also Regulation (EC) 258/97

Novel Food Regulation 142 see also Regulation (EC) 258/97

Novo yeast cream 513

nucleic acid sequence-based amplification (NASBA) 353 see also NASBA
NucleoMag 96 Plant Kit 324-325

Nucleospin 466-471

evaluation for DNA extraction

from feed $468 \mathrm{f}$

from lecithin $\quad 468 \mathrm{f}$

from maize grain $468 \mathrm{f}$

rom soya lecithin $469 f$

from tofu 468

oilcakes 215

oil(s) 228

DNA extraction from 318

oilseed rape (OSR) 26-29, 143t, 274, 276t, 375f, 376f, 504t, 505-506

AGMP rates $55,56 \mathrm{t}$

background pollen 58

BnaDFFS collection 288

Brassica rapa $28,29,31,66,73,288$

characteristics of $24 \mathrm{t}$

cleistogamy 64 see also bioconfinement and biological containment

co-existence of GM and non-GM 28-29 over time 29

in space 29

collections of 287-288

cost calculations in single and compound food/feed value chains $179 t$

cost for non-GM production in Germany of $185 f$

costs of co-existence and segregation of

cropping systems $\quad 54-56$

cross-pollination

between crops 26-27

and volunteers 146-147

crushing 149

decline of the seedbank from the last known crop $27 \mathrm{f}$

effect of changes in farming practices on harvest impurity 56

EU production of 216

evaluation of gene flow in oilseed rape with cropping system models 49-60

ferals 28

gene flow model 50

GENESYS model 50

$S$-glucosyl transferase 276

GM oilseed rape 57

GT73 Rapeseed 506t

imports 149

landscape 56-58

background pollen 58

flexible measures 58

isolation distances $57,58 \mathrm{f}$

objective and simulation plan 56

regional crop proportions $56-57$ local measures 53-54

buffer zones vs. harvest discarding

insufficiency of 54

objective and simulation plan 53-54

model analysis and evaluation 50

Ms8 Rapeseed 505t

Ms8 x Rf3 Rapeseed 505t

perspectives of the modelling and simulation study 58-59

potential for crossing and introgression $24 \mathrm{t}$

pre-sowing seed admixture

certified seed lots $52-53$

effect of GM and non-GM seed lot characteristics 52

objective and simulation plan 52 reference assays $275,276 \mathrm{t}$ see also endogenous reference gene/ system

acyl-acyl carrier thioesterase $276 \mathrm{t}$

arginine decarboxilase $276 t$

at 1 g53101 0 osr mapping $276 \mathrm{t}$

cruciferine $276 \mathrm{t}$

high mobility group protein 276

phosphenolpyruvate carboxilase $276 \mathrm{t}$

Rf3 Rapeseed 505t

screening table $373 \mathrm{f}$

seeds 49

simulation methodology $51-58$

objectives and simulation steps 51-52

pre-sowing seed admixture $52-53$

T45 Rapeseed 504t

testing of transgenic mitigation 73

tilling and secondary seed dormancy in 72

transgenic mitigation 73

transmission of chloroplast DNA through hybridisation with wild relatives 66

varietal association (VA) OSR 27

varieties 53

cropping systems 53

gene flow between varieties in contrasted scenarios 53

objective and simulation plan 53

volunteers $27-28,56,204$

GENESYS model $50,51 \mathrm{f}$

management to reduce adventitious presence 28

persistence and longevity 27

wild relatives 28

see also Brassica, canola and rapeseed

oligoplex/multiplex PCR assays 335

oligoplex PCR 334, 336-337, 361-362

oligoplex PCR-AGE 337-338

oligoplex PCR-CGE 340-346

oligoplex PCR-CGE-LIF 342 
oligoplex PCR-CGE-SC 343, 345f onions 67

OPACSA (software) 247, 267 see also sampling

opinions and attitudes 4-6 see also consumers

orchids 69

Orf, James 93, 99, 106

organic farming 225

organic supply chains 424

OSR see oilseed rape

outcrossing rate (OCR) 256, 257, 265

critical field lengths for measuring $262 \mathrm{f}$

data mining and modelling of the spatial variability of the 258-259

determining mean OCR, edge type of the field 260-261

for different field types 259

estimation of the OCR in the field using fitting functions 259-260

visualisation of spatial variability of OCR using geostatistic tools 257-258

Owen cytoplasm 38, 41, 42, 45 see also bioconfinement and biological containment

$\mathrm{P}$

padlock ligation detection $361 \mathrm{f}$

padlock ligation microarray system 335

Palmer's pigweed 569

PANZEA 287

papaya $4,521,524,526,533$

Paraguay $545,606 \mathrm{t}$

share of soybean harvest exported to the EU-27 606t

soybeans imported to EU-27 606t

parallel PCR screening 361

parallel semi-quantitative event-specific screening 351

parthenocarpy 68-69

patents $94,97,110$

and plant breeders' rights 94

soybean 96

payoffs $597 \mathrm{f}$

base case extensive form game and theoretical payoffs $597 \mathrm{f}$

base case payoffs $598 \mathrm{t}$

PCR see polymerase chain reaction (PCR)

PCR amplification efficiency 389

PCR-CGE-SC 342

PCR forming unit (PFU) 313 see also most probable number

penalty costs 601

penta(5)-plex PCR-CGE-SC $344 t$

pentaplex PCR 342

performance characteristics 320-321

Perkin Elmer MultiPROBE II $\quad 326,327$ personal injury 407

pest management 181

petunia 65

PFAR see publishable final activity report

PCR-CGE method 388

the Philippines 36,288

phosphenolpyruvate carboxilase $276 \mathrm{t}$

Phospholipase D 276t

Picogreen 298t

PicoGreen fluorometric DNA quantification 297

pig feed 215

pig production, regulation of 425

piglet feed $234 \mathrm{f}$

pizza, GM ingredients in 180

pJANUS-02-001 dual target plasmid 300 , 388 see also calibrant, reference materials and CRM

PL73 Brevibacterium 513t

plant variety lists 289

Plant Variety Protection (PVP) certificates 96, 97, 98, 107

plants, genetic engineering in 543

plasmid DNA (pDNA) 299, 300, 392, 535

plastids 65

Plexor technology 319

Plus-Hybrid System 67 see also bioconfinement and biological containment

Plus-minus-1 analysis 474, 481, 485

Poland 182, 189

compound feed case studies 187

cost calculations in single and compound food/feed value chains $179 \mathrm{t}$

cost of co-existence and segregation for compound feed production $188 \mathrm{t}$

cost of co-existence and traceability of rapeseed oil $182 \mathrm{t}$

estimated production of compound feed $216 f$

imports from Ukraine 149

oilseed rape seeds 145

supply chains analysed $143 \mathrm{t}$

Pôles d'excellence rurale (PER - clusters of rural excellence) 578 see also land

agricultural 578-579

and clusters $\quad 579-580$

social and environmental 578

pollen 82,626

background pollen $25,39,40,58$

colchicin-induced auto-tetrapoloid pollen donors 41

contributions of pollen and seed to impurities in crops 23-34

dispersal see also gene flow in large fragmented landscapes $79-87$

in maize 79

model evaluation $50,52,82-83,627$

modelling regional pollen transport 81-83

atmospheric model 81

conclusions and perspectives 84-86

conservation equations for pollen 81-82

mapping regional pollen sources $82-83$ results 85

simulated regional pollen dispersal 84

in sugar beet $39-40$

plastid DNA transmission through 65-66

transmission of transgenes through 62

viability $82,83,84 \mathrm{f}, 86 \mathrm{f}$

pollination 27,30

see also cross-pollination

polymerase chain reaction (PCR) 150 153, 162, 167, 303, 307, 309, $333,334,377,389,525$

analysis of flint maize in Argentina 152

Anchor PCR 230

application to whole supply chains 9 and automatic downgrading strategies 172-173

automation of 327

detection of PCR products by hybridisation in array format 346-353

digital PCR combined with highthroughput nanofluidic QRT-PCR 311-313

DNA extraction and 389

efficiency and matrix influence 297-299

importance of the specificity and uniformity of reference PCR systems $274 \mathrm{f}$

influence of DNA extraction method on efficiency of $298 \mathrm{f}$

issues for stakeholders 220

multiplex universal PCR and array based detection $347 \mathrm{f}$

properties of $355 \mathrm{t}$

setup automation $\quad 326-327,328$

technologies for the detection of PCR products 337-353

polymerase chain reaction (PCR)-based methods

estimation uncertainty for 393-394, $395 f$

expression of uncertainty for 393

standardised results from $394 \mathrm{f}$

polymerase chain reaction (PCR) forming unit (PFU) 313 see also MPN 
pork $228,231,545,546,548,550,551$, 552

pork feed $234 \mathrm{f}$

Portugal 4, 178, 216f, 553, 584

post-market environmental monitoring (PMEM) 11, 630 see also general surveillance

potato metalo-caroboxypeptidase inhibitor gene 277

potato(es) 141, 143t, 274, 276t, 375f, 376f, 504t

cross-pollination and volunteers 147

EH92-527 Potato 504t

European cultivated potato database 288

identification of critical points for GM and non-GM admixture in fresh potato $144 \mathrm{f}$

processing of fresh 150

reference assays $277 \mathrm{t}$

potato metalo-carboxypeptidase inhibitor gene $277 \mathrm{t}$

TATA binding protein gene $277 \mathrm{t}$

UDP glucose pyrophosphorilase gene $277 \mathrm{t}$

screening table $373 \mathrm{f}$

poultry $152,153,231,424,425,545$, $546,550,551,552,553,554$

feed $153,215,374$

meat 231,374

powdered milk 550

pre-audits 236

pre-packed products

distribution of RRS (RoundUp Ready Soybean) percent in $250 \mathrm{f}$

percentage errors for a range of samples $250 \mathrm{f}$

sampling methods for 249-251

SISSI-based confidence limits of GM content for $250 \mathrm{f}$

precaution

and the scientific method 435-443

and scientific substance 443-447

precautionary measures, judge's role concerning science in 433-457

precautionary principle $7,9,12,293$, $448-451,454,620$

precision 384

intermediate precision 384

repeatability 384

reproducibility 384

premiums 599 see also price

effect of supplier and farmer incentive premiums on acceptance probabilities $599 \mathrm{f}$

required for contracting strategy $600 \mathrm{f}$

prevention strategy 191

price 119,121 premium 189

primary gene pool 281

primer-based chemistry assays 319-320

private insurance 411-412 see also

compensation, insurance and redress

private regulations $\quad 611-612$

probe-based chemistries 320

procedural control 449

process models 482

processes

assessment of $482-485$

schematic overview of $482 \mathrm{f}$

processing 149-150

Procumbentes 36

procurement practices 603

producers 410

product liability 409-411

product segregation systems $\quad 184-186$

product testing 162

production chain

designing control plans 252

efficient control along 251-252

viewed as a sequence of processes $482 \mathrm{f}$

production costs 251-252

of GM and non-GM feed in Belgium 221-222

production location 122

property, damage to 406

property rights 205

proportional liability 207, 408

protein meals 180,215

public good attributes of GM and non-GM goods 196

Publishable Final Activity Reports (PFAR) 3

pure economic loss 407-408 see also losses

PVP certificates $\quad 96,97,98,107$

Q

QRT-PCR machines 327

qualitative duplex real-time PCR

$$
\text { 339-340 }
$$

with IPC 340

qualitative multiplex assays 361

qualitative oligoplex real-time PCR 340 , $341 \mathrm{f}$

qualitative PCR $222,311,334,339,377$, 531

quality control material 391

quality signs $6,543,548,628$ see also $\mathrm{AOC}$ and labels

quantification limit 384 see also limit of quantification, LOQ and LOD

quantitative differential PCR 335, 379 see also GMO analysis, GMO detection, matrix approach and unauthorised GMOs quantitative duplex real-time PCR 338-339

for detection of Roundup Ready soybean in processed foods 339

quantitative GMO analysis 335

quantitative multiplex assays 361

quantitative oligoplex (real-time) PCR 339

quantitative real-time PCR (QRT-PCR) 307, 308, 328, 389

QUIZ (quantitation using informative zeros) 311

random sampling schemes 261, 263t see also sampling

rapeseed see Brassica, canola and oilseed rape

oil $118 \mathrm{t}, 119,182 \mathrm{t}$

raw materials 316

real-time PCR 298t, 318-321, 338-340 see also quantitative real-time PCR

applicability and cost 355

controlling the bias of 315-317

evaluation of different machines for GM quantification by $321-323$, $324 \mathrm{t}$

molecular basis of different chemistries 318-320

performance 355

properties of $355 \mathrm{t}$

using high-throughput nanofluidic dynamic arrays 312-313

Recommendation 2004/787/EC $\quad 8,9$, 564

Recoverable Block of Function strategy 71,72

Red Bull drink Case 450

redress 9, 10, 408, 412-413 see also compensation, insurance, liability and private insurance

liability and redress options for damage caused by GMOs 405-413

reference assays 273-274 see also endogenous reference gene/ system

beet $273,275 f, 276 f$

biological aspects when designing 279-280

breeding issues 282-283

core collections for testing of 280-289

definition of $278 \mathrm{t}$

heatmap of endogenous and transgenic assays on a dynamic array $314 \mathrm{f}$

legislation issues 283

maize $277 \mathrm{t}, 287$

oilseed rape $276 \mathrm{t}$

phylogenetic relationship between crop and relatives $280-281$ 
potato $277 \mathrm{t}$

potential for cross-reaction in 286 practicability and cost effectiveness 321

practical issues 283

reliability of $274-277,278$

rice $276 \mathrm{t}$

selection of species for specificity testing of $285 \mathrm{f}$

specificity testing 283

taxonomy and phylogeny of the beet complex $275 \mathrm{f}$

taxonomic status of crops 280

technical requirements for testing 278-280

validation of 290

reference materials 299-300 see also calibrant, CRM and JRC-IRMM

method validation and 383-401 see also CRL-GMFF, EURL-GMFF and JRC-IHCP

system 274f, 278t see also calibrant, CRM, JRC-IRMM and reference assays

regional model (RM) 482-483

Registration Requirement for Genetically Modified/Soybean and Genetically Modified corn 532

Regulation see also Directive, Legislation and Recommendation

Regulation (EC) No 50/2000 142

Regulation (EC) No 65/2004 496t

Regulation (EC) No 178/2002 8, 191, 223, 224, 422, 494, 595, 605, 608, 611, 615 see also General Food Law

goals of 178

principles and requirements of 142

Regulation (EC) No 183/2005 223, 224, 422

Regulation (EC) No 258/1997 142, 178 see also Novel Food and Ingredient Law

Regulation (EC) No 641/2004 496t, 498

Regulation (EC) No 757/2003 566

Regulation (EC) No 852/2004 224

Regulation (EC) No 882/2004 497t, 498, 499 see also National Reference Laboratories

Regulation (EC) No 1829/2003 177, 217 , 273, 293, 304, 478, 493, 494, 495, 497, 498, 595

enactment of 142

GMO detection methods validated by the CRL under 499

and labelling of feed products 154 , 178

publication and key provisions of $496 \mathrm{t}$
Regulation (EC) No 1830/2003 142, 154 , 177, 178, 203, 217, 246, 248, 293, 422, 496t, 611

Regulation (EC) No 1946/2003 497t

Regulation (EC) No 1981/2006 496t, 498

regulations 223,406

private $611-612$

regulatory and responsibility frames $7-8$

regulatory frameworks 6

relative limit of detection (LODr) 343 , 347 see also absolute limit of detection, limit of detection and LOD

relative LOD/LOQ 310 see also relative limit of detection

relative standard deviation 322 see also bias and measurement uncertainty

relative standard uncertainty (RSUA) 251, 252 see also bias and measurement uncertainty

reproducibility standard deviation 394 see also bias and measurement uncertainty

research 8, 229-230

programmes $3,10-11,288,418$

resources

\section{activation 577}

equity-oriented conception 575

exploitation of 575-577

human resources 574

ideal conception 575

intangible resources 574

making full use of 575-578

material resources 574

in the post-Fordist era $574-575$

specification 577

in territories $574-575$

utilitarian conceptions 575

see also genetic resources and germplasm

rice $4,274,327,375 f, 376 f, 503 t, 504 t$

American broken rice 622

cleistogamy 64 see also

bioconfinement and biological containment

collections of 288

detection of sequence motifs in transgenic 379

LLRICE62 Rice 503t

LLRICE601 Rice 504t

reference assays $276 \mathrm{t}$ see also reference assays and endogenous reference gene/system

phospholipase D $276 \mathrm{t}$

root specific gos $9276 t$

sucrose phosphate synthase $276 \mathrm{t}$

screening table $373 \mathrm{f}$

Senegalese rice 622 risk assessment $\quad 3,435-436,523,627$

according to the potentially applicable health measures 441

adaption to the evolution of the scientific evidence 437

carried out by WTO member states 437

credible risk $445-447$

data representing the dominant opinion versus data representing a minority opinion 441-442

data to collect to carry out 441

evaluation of the possibility or probability of a risk 439-440

high-quality and relevant 437-438

minimum risk threshold 443

most recent available data $442-443$

national and international research results 442

plausible risk $445-447$

possible risk 445-447

precautionary measures 443-445

probable risk 445-447

quantitative and qualitative 437

reflecting real conditions of the real world 440-441

related to the precise anticipated risk 439

type of experts entrusted for 438

uncertainty level and 436

using as a simple alibi 436-437

risk perception $\quad 6-7$

risks

dread risks 593

information about 208

uncertain risks 593

RNA transcript sequence analysis 380

Romania, estimated production of compound feed $216 f$

Rome Treaty 418, 563

root specific gos $9276 \mathrm{t}$

Round Table on Responsible Soy (RTRS) 236

Roundup see also glyphosate

Roundup Ready soy (RRS) 93, 229, 247. 300, 301f, 338, 339

Roundup Ready soybean (RRS) $345 f$

Roundup Ready sugar beets 39

Russia 3, 35, 36

safety regulations

or tort liability 207-208

and tort liability 208-209

Salmon Case 440, 441, 446

sampling 9, 499-514, 626, 627, 629

and analysis budget 253

assessment of sampling methods $472-477$

development of approaches 259

feasibility of sampling schemes 261 


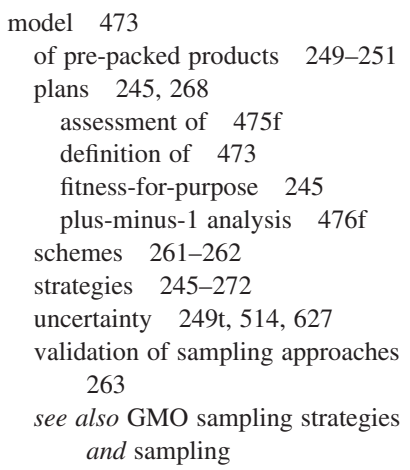

seed contamination 421

seed germination blocking 71

sugar beet 42,44

see also soybean seeds, bioconfinement, biological containment, GURT, T-GURT and V-GURT

segregation $\quad 602,605$ see also coexistence and identity preservation

costs for the feed manufacturer 220-223

at feed manufacturing level 219

and traceability between GM and non-GM supply chains of single crop and compound food/feed products, costs of 177-191

regulations $591,592,603$

strategies $154 \mathrm{t}$

spatial segregation 128,155 566-568

temporal/time strategy 128

SENASA $\quad 609,612$

sensitivity 308, 599-602

sensitivity analysis $167-170$

outputs $\quad 168-170$

parameters 167-168

scenarios 168

Sesamia nonagrioides see Mediterranean corn borer

sheep 548, 553

SIGMEA project $11,23,24 \mathrm{t}, 27,29,32$, 86

silo bags 152

silos 152

SIMQUANT (single molecule quantification) $311,328,388$, 471

simulation parameters $600 \mathrm{t}$

single crops, costs of segregation and traceability between GM and non-GM supply chains of compound food/feed products and 177-191

single laboratory validation 338 , 385-386 see also collaborative validation of methods,

CRL-GMFF, EURL-GMFF and JRC-IHCP

single molecule quantification (SIMQUANT) 311, 328, 388, 471

single nucleotide polymorphism (SNP) $317,335,357-358$ see also ligase chain reaction and SNPlex

based assay 377

SISSI software $248,249,250,251,267$

site fitness 466

Skiff, Jim 93

Slovenia 361

risk of admixture on farms 147

supply chains analysed 143 small operators 430

SNP see single nucleotide polymorphism

SNPlex PADLOCK ligation microarray 357-361

SNPlex technology 360 see also ligase chain reaction

social benefits, of co-existence 591-593

social insurance 411

software see AMPE, decision support system, DEXI, GENESYS, KeSTE, MAPOD, OPACSA, Seedcalc, SISSI and WEKA

sorghum 67,287

sound science 620

South Africa 4, 36, 230

South America $233,235,287,550$, 609

see also Argentina, Brazil, Latin America and Mexico

South Korea 36

sow feed $234 \mathrm{f}$

see also pig feed; piglet feed

soy 276t, 427, 547 see also soya and soybean

Brazilian case study on traceability and segregation of non-GM soy 227

cost calculations in single and compound food/feed value chains $179 \mathrm{t}$

for food case study 156

GM soy

in animal feed 253-255

price evolutions of $235 f$

GMO-free soy 550

GMO-free soy supply, containment policy 551

Roundup Ready soy 93, 229, 247, 300, 301f, 339

transportation of 480

soy meal, imported by EU 606t

soy oil, imported by EU 606t

soy sauce 533

soya see soy

soya beans see soybeans

soybean elevators 232-233

soybean lecithin, DNA extraction from 318

soybean meal

EU production of 216

Lo-Pro soybean meal 215

soybean oil, DNA extraction from 318

soybean seeds

availability of non-GM 89-112

concentration in the US soybean seed industry $97 \mathrm{f}$

market share evolution for varieties of $96 \mathrm{f}$

soybean supply chain 141

GMO labelling 536-538 
soybeans 143t, 153, 255, 375f, 376f, $507 \mathrm{t}, 508 \mathrm{t}, 511 \mathrm{t}, 605$

A2704-12 Soybean 507t

A5547-127 Soybean 511t

availability of non-GM soybean seeds in USA $99 t$

breeding activity 96-97

competitive challenges facing small breeders 107

cross-pollination and volunteers 146

crushing 149,233

demand for non-GM soybeans 92

DNA quantification methods

soybean grain $298 \mathrm{t}$

soybean milk $298 \mathrm{t}$

DNA, soybean feed $298 \mathrm{t}$

DP-305423-1 Soybean 511t

DP-356043-5 Soybean 511t

future of public research on soybean breeding 105

germplasm 97-98, 106-107

global competitiveness of 106

global market 90-91

GM soybeans

in Mercosur countries 606-609

price evolutions of $234 \mathrm{f}$

imported by EU 606t

imports into the EU 216

integration of GM traits in 110

intellectual property rights for plant breeders 94

Kumen $4500 \quad 103$

market concentration in the USA 95-98

matrices $299 \mathrm{f}$

mergers and acquisitions in the soybean seed industry 95

MON 04032-6 Soybean 507t

MON 89788 Soybean 508t

non-GM breeders

characteristics of varieties 100

future of 104-108

state universities 99-100

varieties released by state universities 100

non-GM market 91-92

non-GM seed breeders, and availability of non-GM seeds 98-100

non-GM soybean seeds in Argentina 102-104, 108-109

non-GM sulfonylurea herbicide-tolerant 421

patents and PVP certificates 96

production $90 \mathrm{f}$

GM and non-GM planted areas in the USA $90 \mathrm{f}$

of non-GM 91-94

Roundup Ready seeds 93

Roundup Ready soybean $345 \mathrm{f}$

RRS soybean, uncertainty profile 396

sampling of 474 screening table $373 \mathrm{f}$

share of soybean harvest exported to the EU-27 606t

soybean industry leaders and availability of non-GM soybean varieties in the USA $107-108$

soybean products in animal feed 215

soybean products used in animal feed 215

supply of non-GM varieties for general use $107 \mathrm{t}$

varieties with IPRs 97

space, discontinuity and heterogenous 586 see also land

Spain 410

Bt maize in 127

cross-pollination study 25

cultivation of GM crops in 543

equipment sharing 147

estimated production of compound feed $216 f$

standard field sampling system 256

supply chains analysed $143 \mathrm{t}$

transport and reloading of maize 148

transport and storage of maize 147

volunteers in maize 26

spatial segregation $\quad 566-568$

species, definition of $278 \mathrm{t}$ see also reference assays and endogenous reference gene/system

specificity 384

specificity testing 284-286

Spinacia oleracea $276 \mathrm{t}$

stacked gene see gene stacking

stakeholders, network of $573 \mathrm{f}$

standards 9, 294, 397, 406

Standing Commission for Feedstuffs 438

Standing Veterinary Committee (SVC) 438

starch maize supply chain $\quad 161-175$

aim of model 162

batch control 165-16

batch scheduling 165

control systems 165

estimating GM content as percentage of DNA bearing the transgene 166

GM adventitious presence quantification $166-167$

material flow and risks of commingling $162-163$

model 483,487

basic attributes for the $484 \mathrm{f}$

model description 163-167

results and discussion 170-173

sensitivity analysis $167-170$

outputs $168-170$

parameters 167-168

scenarios 168

testing procedure 165

wet-milling process 163,164 starch synthase $277 \mathrm{t}$

statutory compulsory certification system 528

statutory optional certification and mark system 528

strict liability rules 412

Suaeda vera 276

Suber, John 93

sucrose phosphate synthase $276 \mathrm{t}$

sugar $36,185 \mathrm{f}$

sugar beet $35-48,143 \mathrm{t}, 145,276 \mathrm{t}, 281$, $286,375 f, 376 f$

accidental admixture of seed lots 39

admixture in 41

co-existence costs in Germany and Denmark $183 f$

collection routes $45-46$

consequences of co-existence for genetic resources 45

consequences of co-existence for the cropping system of $42-45$

cost calculations in single and compound food/feed value chains 179

cross-pollination and volunteers 147

cultivation of $37-38$

description and domestication 36

expected benefits of GM 38-39

gene flow 35, 42-43

GENESYS-Beet model 43

genetic proximity 37

GM plants pollinating wild beets 41

GM sugar beets 36

harvesting machines 45

herbicide resistance 44 see also case specific monitoring

marketplace 35-36

Owen cytoplasm 41, 45 see also bioconfinement and biological containment

phylogeny see 275

plant breeding 38

plant selection scheme 41-42

pollen dispersal 39-40

post-harvest co-existence issues 45-46

pre-cultivation co-existence issues $39-42$

production areas 35

proximity of GM and non-GM nurseries

recommendations by inter-professional organisations 44-45

reference assays 276f see also reference assays and endogenous reference gene/system

rotation 44

Roundup Ready sugar beets 39

RUR H7 Sugar beet 501t

screening table $373 \mathrm{f}$

seed migration in 41 
seeds $\quad 42,44$

taxonomy 36-37

and phylogeny $275 \mathrm{f}$

volunteer beets 42

weed beet demography model 43-44

weed beet pollen invasion in the nursery $40-41$

and weed beets 42

weed control in 38

see also beet, Beta, sea beet and weed beet

sugar cane 35,36

suitability checks 385

sunflower $67,225,545,546$

supply, and demand 426

supply chains

agricultural production and 622-623

analysis of co-existence in commodity supply chains $141-160$

co-existence of 9-10

commodity supply contracts $426-428$

GM-free supply chains $\quad 424-426$

import supply chains and GMOs 424-428

organic supply chains 424

and regions analysed 143

sampling see GMO sampling strategies and sampling

segregation of 591-604

structuring 419-424

supply chains analysis

methodology 143-145

results 145-155

transport 148

vertical supply chains 144

surveillance plans 630 see also case specific monitoring and post-market environmental monitoring

SURVEYSELECT 248

Sweden, estimated production of compound feed $216 \mathrm{f}$

Switzerland $147,182,183-184,189$, 430,546

cost calculations in single and compound food/feed value chains $179 \mathrm{t}$

cost of co-existence and traceability of rapeseed oil $182 \mathrm{t}$

cross-pollination study 25

extension of prescriptions 430

pest management 181

supply chains analysed $143 \mathrm{t}$

SYBR Green 319, 32

$\mathrm{T}$

T-GURT (trait-specific GURT) 70

Taiwan 521, 532-534

agricultural products traceability system 533-534
Bureau of Food and Drug Analysis (BFDA) of the DOH 533

GM food labelling 533

GMO detection in 533

National Science and Technology Program for Agricultural Biotechnology (NSTPAB) 533

National Science Council (NSC) 533

Plant Variety and Plant Seed Act 533

regulatory framework of GMOs in 532-533

Taiwan Seed Improvement and Propagation Station (TSIPS) 533

TaqMan probes $247,320,321,328,338$

TATA binding protein gene $277 \mathrm{t}$

taxon, definition of $278 \mathrm{t}$ see also reference assays and endogenous reference gene/system

Tecan 298t

technology label 293

Terminator 625 see also bioconfinement, biological containment, GURT, T-GURT and V-GURT

territoriality $582-584$

and the environment $584-585$

historical dimension 582-583

territories see also land

co-existence in $580-585$

community initiatives 586

at the core of a network of different social actors and partners 572-574

debate and governance 581-582

diversity 581

exploitation and specification of resources 575-577

geographical scale and governance 581-582

from the populations who live there and rural areas not restricted to agricultural populations 572

quality-oriented approach 587

resources in $574-575,576 \mathrm{t}$

understandings 587

Thailand 36, 606

third countries 196

co-existence and traceability in the EU versus IP systems in 605-616

see also Mercosur countries

third world countries 237

threshold values $8,9,10,78,86,204$, $255,256,267,387,398$

thresholds $39,40,45,51,86,283,286$, $547,549,550,552,564-566$, $614,626,627,629$

tilling 72

tobacco $64,65,73$

tocopherol 228 tomato(es) $118 \mathrm{t}, 119,141,143 \mathrm{t}, 145$

co-existence of GMO and non-GM 156

cross-pollination and volunteers 147

price consumers willing to pay (WTP) 123

processing 150

supply chain in Belgium 150

tort law 207, 406, 407, 408-411, 412

tort liability 207-208 see also compensation, liability and redress

Touvet, Laurent 447

traceability $178,202-204,371,422,602$, $612,628-629,630$

in Argentina and Brazil 426

assessment of products using traceability data 477-481

and co-existence in supply chains 215-241

cost of segregating wheat to conform to EU standards 595-596

in $\mathrm{EU}$ and Mercosur countries 610-611

EU legislation on GMO 494-495

exemption from traceability requirements 495

failure of 245

at feed manufacturing level 219

integration of Co-extra results in EU tools for $493-520$

introduction to $3-20$

management of 12

overview 628-629

political aims of 423-424

and segregation at feed manufacturing level 219-220

and segregation at import 218

and segregation between GM and non-GM supply chains of single crop and compound food/feed products, costs of 177-191

and segregation systems 218-224

studies on aspects of systems of 596

as a technical issue $\quad 422-423$

truck traceability 46

see also measurement uncertainty and sampling

traceability frame $\quad 8-9$

traceability regulations $591,592,603$

traders, in the EU and Mercosur countries 613-614

training courses 516

Transcontainer 10,11

transcriptomics 380

transgenes 31

biological containment of 61 see also bioconfinement and biological containment 
transmission of 61

transmission through pollen 62

see also gene flow and pollen dispersa transgenic crops

apomixis $\quad 69-70$ see also

bioconfinement and biological containmen

biological containment $\quad 61-77$ see also bioconfinement and biological containment

auxotrophy 62

cell-lethal gene expression 63

flowering inhibition and complete sterility $62-63$

introduction 61-63

position in plant life cycle $62 \mathrm{f}$

chloroplast transformation $\quad 65-67$

cleistogamy 63-64 see also bioconfinement and biological containment

flowering inhibition 63 see also bioconfinement and biological containment

male sterility 67-68 see also bioconfinement and biological containment

parthenocarpy 68-69 see also bioconfinement and biological containment

seed dormancy inhibition 72 see also bioconfinement and biological containmen

seed germination blocking 70-72 see also bioconfinement and biological containment

seed shattering 70 see also bioconfinement and biological containment

transgene excision $\quad 64-65$

transgenic mitigation $72-73$

transmission of 61

see also GM crops

transgenic DNA 333

transgenic mitigation $72-73$

Transmissible Spongiform Encephalopathy (TSE) 436, 445, 446 see also bovine spongiform encephalopathy (BSE)

transportation model 478-481, 487

attributes of $480 \mathrm{t}$

evaluation of the bulk maize transport by the $481 \mathrm{f}$

plus-minus- 1 analysis results $481 \mathrm{f}$ selective explanation of the bulk maize transport $481 \mathrm{f}$

structure of 479,480

Treaty of Amsterdam 439

Treaty of Maastricht 293

Treaty of Rome 418, 563

trueness $327,384,536$
UDP glucose pyrophosphorilase gene $277 \mathrm{t}$

UGM (unauthorised GMOs) model $477-478,479 t, 481,487$

attributes $479 \mathrm{t}$

AnalyticalMethods 478

GeographicalOrigin of the product 477

Logistics $\quad 477-478$

SystemsUsed in previous stages of the supply chain 477

hierarchical structure of $477,478 \mathrm{f}$

unknown GMOs 367-380

Ukraine $35,149,553,554,555,622$

unauthorised GMOs (UGM)

detection of $356,378-379$

qualitative detection of $378-379$

quantitative detection of 379

sources of 368

uncertainty 398

in GMO sampling 245

profile 395-396

see also bias, GMO sampling strategies, measurement uncertainty and sampling

uncertainty, situation of $7,12,619,621$

understandings $580,583,584$

uniformity testing 284,286

of RA for maize 287

unit of measurement 516

United Kingdom 121, 122, 123, 124 , 553,620

demand for non-GM food 229

estimated production of compound feed $216 f$

Farm Scale Evaluation 10

imports 149

supply chains analysed $143 \mathrm{t}$

United States of America 4, 35, 94, 209 , $216,231,237,545,606$

attitudes towards GMOs in opinion polls 194-195

availability of non-GM soybean seeds in $89,99 \mathrm{t}, 109$

concentration in the soybean seed industry $97 \mathrm{f}$

demand for non-GM food 229

demand for non-GM soybeans 109

future of public research on soybean breeding 105

$\mathrm{GM}$ and non-GM planted areas in the $90 f$

GMO/nonGMO labelling 193

IP (identity preserved) corn rose 608 see also coexistence and segregation

judges approach in 454

labelling of GMO and derived products 6 legal use of scientific knowledge 453-454

mergers and acquisitions in the soybean seed industry 95

National Plant Germplasm System (NPGS) 288

non-GM breeding and seeds in 94-100

non-GM soybean breeders 105

state universities 99-100

non-GM soybean seeds in 109

plant variety protection system 95

production of GM, costs of 93

production of non-GM soybeans in 92-93

rBST milk 203

Roundup resistant plants 569

share of soybean harvest exported to the EU-27 606t

soy meal exported to the EU-27 606t

soy oil exported to the EU-27 606t

soybean breeding industry, public financial resources 105-106

soybean crushing 233

soybean industry leaders and availability of non-GM soybean varieties 107-108

soybean market concentration $\quad 95-98$

soybean production in 90, 217

soybean seed sellers $95-96$

soybeans exported to EU-27 606t

supply of soybeans 235

trends in the supply of grains in $608 \mathrm{f}$

universities 99-100

unknown GMO (UGM) detection 367-382 see also UGM

application of genomics 379-380

application of transcriptomics 380

DNA sequence based analysis 379-380

RNA transcript sequence analysis 380

Uruguay 606

share of soybean harvest exported to the EU-27 606t

soybeans imported to EU-27 606t

US National Plant Germplasm System (NPGS) 288

V-GURT (variety-level GURT) 70, 71f see also bioconfinement, biological containment, GURT and T-GURT

validation (of detection methods) 303 , 383-385

collaborative validation of methods 386-387

in-house validation 385

modularity $388-390$ 
retrospective validation $\quad 385-386$ single laboratory validation $\quad 385-386$ see also CRL-GMFF, EURL-GMFF and JRC-IHCP

Vallaux, Camille 569

valuation methods

hypothetical valuations 197

non-hypothetical valuations 199

in experimental settings 197

in real markets 197

see also consumers, GM food

valuation studies, WTA and WTP

value

non-use value 196,199

use value 196

varietal association (VA) OSR 27

variety-level GURT (V-GURT) 70, 71f

variety see cultivar

veal 548

vegetable beets, consequences of co-existence for genetic resources 45 see also beet, Beta, genetic resources, germplasm, sea beet, sugar beet and weed beet

voluntary actions 425

volunteers $23,30,31,146-147,163,256$

beet volunteers 42

density in agricultural fields 264

evaluation of the proportion of volunteers that reached the flowering stage 264-265

maize 26

oilseed rape volunteers $\quad 27-28$

Walter Hahn Case 450

Warburton IPPM system 186t weed beet 42

demography model $\quad 43-44$

genetic diversity of 43

pollen invasion in sugar beet nursery 40-41

see also beet, Beta, sea beet and sugar beet

weedkillers see glyphosate

weeds, resistant 630

Weiser, Phil 95

WEKA dating mining software package 258

wet-milling process $162,163,164$

WGA see whole genome amplification

wheat 143t, 215

cost calculations in single and compound food/feed value chains $179 \mathrm{t}$

costs of co-existence and segregation of 181

costs of segregating wheat to conform to EU traceability standards 595-596

cross-pollination and volunteers 146

flour 179t, 180, 182

German and Danish cost structure for producing non-GM wheat products at industry level $184 \mathrm{t}$

GM wheat 595, 602

hard red spring wheat 597

non-GM wheat contracting strategy 595

North American 595

salinity resistant Chinese wheat 420n

studies on wheat marketing strategies 596

tilling and fatal germination in 72

see also corn wheat starch supply chain

adjusting model for $179 \mathrm{f}$

cost for non-GM production in Germany of $185 \mathrm{f}$

white sugar 36

whole genome amplification (WGA) 335

wild sea beet see sea beet

wine 582

World Trade Organization see WTO (World Trade Organization) and GATT

WTA (willing to accept) 197, 211 see also GM food valuation studies and valuation studies

WTO (World Trade Organization) 433, $438,453,454,550,555$

assessment accuracy 439

Dispute Settlement Bodies and Panels 438

possible risk 446

risk assessment 439

and the scientific justification of measures 450-451

WTP (willing to pay) for non-GM food products $116,120,122-124$ 194, 197-201 see also GM food valuation studies and valuation studies

Zea mays see maize and corn

zones 571

buffer zones $25,26,53,54,151,152$ $181,189,209,226,413,418$, 566,583

compliance with 568

vs harvest discarding 54

see also club, cluster coexistence and dedicated production area 124 